\title{
'Race' and the Politics of Land Loss: Colonising Discourses for Patuheuheu and Ngāti Haka
}

\section{Introduction}

This article argues that the racial discourses of the nineteenth century had an adverse impact on the ways in which Māori were treated and indeed, informed and justified colonial methods for separating Māori from their land. As a consequence of Pākeha representations of Māori as Other, Patuheuheu and Ngāti Haka - two closely related clans from the Tūhoe tribe - were subjected to oppressive practices which made it easy for Pākeha to unjustly procure land to the detriment of Patuheuheu and Ngāti Haka identity and wellbeing. This article examines Māori, Patuheuheu and Ngāti Haka land loss using multiple and interdisciplinary theoretical lenses, and posits that these losses were caused, in part, by Pākeha racism.

Historically, white cultures have been associated with intellectual development, refinement, knowledge, established institutions, law and order, and civilised refinement (Hall, 1997). In contrast, black cultures have been constructed and polarised as Other by their colonisers: represented as reactive, emotional, deviant (Hall, 1997), and as the opposite of the civilised ideal (Said, 1978). The perceived differences between the races were substantiated by biological ideas which argued that the there were real genetic differences between people of different skin colours. Since Māori were subjected to racism by the colonising and hegemonic imposition of Western values and norms, problematising the notion of race in the Aotearoa New Zealand context is important. This article will argue that 
racial discourses formed the basis for representations, caricatures and stereotypes which significantly weakened the position of Māori. In this way, structural impediments were created which were motivated by desires for the increase of Pākeha political and economic power, which justified the aggressive colonial land taking activities of the nineteenth century.

In the nineteenth century a Pākeha Native Land Court interpreter named Harry Burt, befriended the community of Te Houhi, one of the traditional home-sites of Patuheuheu and Ngāti Haka. The tragic consequence of that friendship, was that Patuheuheu and Ngāti Haka lost their land through Burt's manipulation of the Land Court system, which deliberately disadvantaged Māori, and was used by Pākeha, like Burt, to engage in illegal and deceitful land purchases (Binney, 2001a, 2002, 2009a; Boast, 2003, cited in Brookfield, 2004; Boast, 2008; Pouwhare, 2004; Ranui, 2004). The Land Court operated on the basis of a number of assumptions about Māori, and since colonial contact, Māori have been constructed by the British as racially, culturally and intellectually inferior and Other. Miles (1989) states that the Other has been represented as a biologically different race whose inferiority was fixed and unchanging. Therefore, ideas which represented Māori as racially inferior and too inherently lazy to own land, were justified by a whole genealogy of racial thought which informed colonial thinking, and therefore had an effect on the way in which Māori were treated in social, political and economic terms, in the nineteenth century and beyond.

\section{An Exploration of Race}

Throughout the seventeenth to nineteenth centuries the widening European gaze, which used ideological justifications for colonial exploitation, pervaded and invaded foreign lands (Spoonley, 1995). Accordingly, European countries such as 
England, Spain and France engaged modes of colonial expansion and extended their military operations in conquest (Johnston, 1998). During that colonial expansion, the colonisers brought with them their belief systems which were imposed on those whom they colonised. In that respect, Aotearoa New Zealand was no different from India, Australia and every other country colonised by the British (or other European countries). The British introduced their class system, their biases and views about gender positions, and their ideas about race and difference.

Categories of race were fabricated at the pinnacle of European empire, to set up divisions between the colonised and their colonisers (Ponzanesi, 2001), in order to systematise and organise people into classifications of difference (Dalal, 2002; Johnston, 2010; Rustin, 1991; Wolfenstein, 1993), which were powerfully reinforced through social and scientific scholarship (Ponzanesi, 2001). According to Christine Bolt (1971) cultural features such as language, and biological traits such as physicality, were used to form the basis of racial classifications, meaning that race moved beyond the biological and became dangerously mixed with the cultural. Thus, the inconsistencies and differences in language, art, history, genetics, rhythm, musicology, athleticism, perceived intelligence, culture, and aesthetics across societies, informed hierarchical taxonomies which ordered people into grades and types (Gates, 1986). These structures, seen as the natural biological order of the world and therefore sanctioned by God (Gates, 1986), represented the races in essentialising ways. According to Tait (1999):

...representations of black bodies remain inscribed with the fantasies and anxieties of our racist histories... biology it has been assumed accounts not only for physical variations like skin colour, but also qualities like intelligence, behaviour and ability... there remains vestiges of its assumptions - for example, a warrior instinct 'in the blood' of Maori men, or sporting or 
muscular ability among blacks due to 'natural rhythm' (p. 207).

Although racial differences are not truly genuine social categories (Daniels, 2008), they have been uncritically and hegemonically accepted as such (Hokowhitu, 2001), while the power of race is embedded in the way that certain racial signifiers govern the distribution of economic and social goods (Farr, 2009). So culturally, socially, politically and economically, race is a problematic and arbitrary social term derived from pseudo-scientific classificatory systems, established to support the positional superiority of European societies above others, allowing Europeans to understand human difference in self-privileging ways (Bolt, 1971; Farr, 2009; Jaimes, 1995; Johnston, 2010; Spoonley, 1995; Root, 1992). It is this position around race that gives us some clues as to how Harry Burt was able to gain control over Patuheuheu and Ngāti Haka lands using the Land Court system, which was designed to take land from Māori and privilege Pākeha.

The word 'race' materialised within an intellectual context which accepted the Bible as a fundamental and authoritative text on human affairs, and first emerged around 1508 in a poem by William Dunbar called 'The Dance of the Sevin [sic] Deidly [sic] Sins' (Banton, 1998). Biblical narratives formed the central tenets on which the Judeo-Christian world was based, and so human beings were considered to be the literal monogenetic progeny of Adam and Eve (Banton, 1998; Goldenberg, 2003; Wall, 1995). But even with supposed common ancestry, not all of Eve and Adam's descendants would be considered equal.

Racial difference in the bible was embodied in the story of Cain, the son of Adam, who was punished by God with a distinguishing mark after killing his brother Abel (Genesis, 4: 1-15); and also Ham and his descendants, cursed to be "servant[s] of servants" (Genesis, 9: 25) by Noah, Ham's father (Banton, 1998; Goldenberg, 2003; Haynes, 2002; Melamed, 
2003; Shavit, 2001; Whitford, 2009). Medieval Judeo-Christian theology defended and circulated racial classifications through interpretations of the Genesis account, based theoretically on the Abrahamic tradition in the Babylonian Talmud, which asserts that human ancestry descended from Noah's sons Japheth, Shem and Ham (Goldenberg, 2003; Haynes, 2002; Wall, 1995; Whitford, 2009). Goldenberg (2003) affirms that "Noah's sons represented three pigmentations of humanity: Ham, the dark races; Shem, the ruddy races (Akkadian sāmu 'red'), and Japhet[h] (Heb. yaphet) the white races..." (p. 146). The Hebrew word 'yapheh', similar to the word Yaphet (Japheth), means 'beautiful' leading some scholars to believe that "...the most beautiful pigmentation is white" (Goldenberg, 2003, p. 146). Conversely, the name Ham means dark, black, hot or brown (Goldenberg, 2003), and so it was believed that "Ham was called Ham because he was black..." (Priest, 1843, p. 46).

In line with this view, Japheth's descendants (Caucasians) were considered morally, physically and intellectually superior, while Shem's darker skinned offspring, which included Polynesians and American Indians, were regarded as 'second best' (Wall, 1995). Ham's lineage were believed to be the lowest form of primitive savage, considered barely human or not human at all, and included Africans, Melanesians and Australian Aboriginals (Wall, 1995). The perceived ascendancy of Japhetic descent is supported in Genesis 9:27: "God shall enlarge Japheth, and he shall dwell in the tents of Shem; and Canaan shall be his servant" (Daly, 2004; Delany, 1879; Banton, 1998; Boyes, 2006; Bush, 1984; Bush \& Mauss, 1984; Haynes, 2002; Mauss, 1984; Melamed, 2003; Goldenberg, 2003; Shavit, 2001; D. Smith, 2003; D. Smith, 2009; Wall, 1995; Whitford, 2009; Yamauchi, 2004).

Late eighteenth and early nineteenth century racial ideas, some of which were based on great chain of being theories, also warranted colonisation and European domination (Bynum, 1975; Gould, 1981, 1996; Giddens, 2009; 
Hokowhitu, 2001, 2003; Jahoda, 1999; Johnston, 1998; Lovejoy, 1964; Miles, 1989, 2003; Schrempp, 1992). The Judeo-Christian God was positioned at the top of the great chain framework, and single celled organisms at the bottom, with all other domains of life situated in between the two poles (Gould, 1981, 1996; Johnston, 1998; Lovejoy, 1964). The realm of humankind was subjected to further gradation in ways which propagated white supremacy, locating 'inferior races' in relation to the ostensible superiority of the white race (Gould, 1981, 1996; Hall, 1997; Johnston, 1998). A poignant example of this is found in a statement from Smellie (1790) referring to black people as lower humans: "Man, in his lowest condition is evidently linked, both in the form of his body and the capacity of his mind, to the large and small orang-outang" (cited in Bynum, 1975, p. 5).

According to 'white views of Indigenous peoples' - from the subtitle of Gidley's (1992) book Representing others: white views of Indigenous peoples - blackness was considered a negative and undesirable trait all over the world. Comments made by Pembroke and Kingsley as they travelled the Pacific, confirm the nineteenth century belief in the scourge of blackness. They stated that the people of Rarotonga "...are still charming, but their mouths and noses are altering [and their] ...face[s are] generally... growing coarser, and one begins to sniff the negro taint from far-distant Papua" (Pembroke \& Kingsley, 1872, cited in Tamplin, 1992, p. 81). Pembroke and Kingsley's comparative description of Māori further maintains ideas of racial hierarchicisation:

The Maori, moreover in spite of his Christianity, seems to possess all the vices of both the western and eastern Polynesians without any of the virtues, except their bravery. He is as idle, immoral, and useless as a Tahitian, without his perfect manners, unselfish generosity and general kindliness. As snobbish, untruthful and avaricious as a Tongan, without his constructive and inventive power, he is a savage to the 
backbone, liking fighting better than any other occupation, and living a much better life when he is fighting than at any other time (Pembroke \& Kingsley, 1872, cited in Tamplin, 1992, p. 81).

Carolus Linnaeus (1707-1778) proposed in 1758 that there were four human classifications; this theory was reworked by Johann Friedrich Blumenbach (1752-1840) to include a fifth human 'type' by 1795 (D. Smith, 2009). Following on from these theorists, Joseph Arthur Comte de Gobineau (1816-1882) posited that there were only three races: Caucasian (white), Negroid (black), and Mongoloid (yellow) (Giddens, 2009; Gould, 1995). Gobineau (1853) claimed that the white race was inherently superior in terms of intelligence, morality and will power, and proposed that yellows and blacks were eternally destined to prostrate themselves at the "feet of the lowest of the whites" (p. 39).

According to Fanon (1986) the whole purpose of racial hierarchies and theories was to "...prove that the Negro [amongst other 'coloured' races] is a stage in the slow evolution of monkey into man" (Fanon, 1986, p. 17), and to construct a sense of white superiority to subdue non-white races (Root, 1992). However some, like Nicholas Hudson (1996) believe that colonial ideology was not based purely on race, but also on the perceived superiority of Western civilisation. Either way, the main factor in colonisation processes is the assumed supremacy of one group over another and the assertion of power and control, and indeed in the Pacific just like in other parts of the world, racial discourse justified colonisation and the taking of Māori/Indigenous lands to civilise and supposedly develop humankind (Boyes, 2006).

The publication of Charles Darwin's (1809-1882) The Origin of Species (1859) and Descent of Man (1872) changed the way that racialised discourse was rationalised; these influential texts ushered in a new paradigm of scientific racism embodied within theories of Social Darwinism (Wall, 1995). Darwin's ideas emphasised differences between so called 
civilised and savage peoples (Hokowhitu, 2009), which were supported by the science of the day, and although his theories accentuated the incongruities between the scientific expositions of human genesis and development, and conventional Christian dogma, rather than dispelling dominant racial discourses, Darwinian ideas actually strengthened them (Wall, 1995).

\section{From Racial Theories to Racial Practices}

Racialised discourse is inseparably connected to the development of rationalist, capitalist, patriarchal and colonial ideologies, and has been used to substantiate and fortify hegemonic relationships between dominant and subordinate groups of people throughout time (Ponzanesi, 2001; Wall, 1995, 1997). Accordingly, conceptualisations of race provided the hegemonic power for the control of the Other and subsequently normalised the economic, political, spatial, and cultural inequalities which exist amongst racialised troupes (Wall, 1995, 1997). It was principally through modes of 'cultural imperialism' that the racialised demarcation of the cultural landscape took place, while the utilisation of the stereotype, as a crucial discursive strategy, reinforced conceptual and cultural tyranny over the Other (Wall, 1995, 1997).

Stereotyping arises in contexts where there are blatant power inequalities, and represents people by using "...'simple, vivid, memorable, easily grasped and widely recognized' characteristics about a person, [which] reduce everything about the person to those traits, exaggerate and simplify them, and fix them without change or development to eternity" (Hall, 1997, p. 258). Moreover, referring to Michel Foucault's power/knowledge analysis, Hall (1997) alleges that stereotyping categorises people in relation to a norm which then, according to Brown (1965), necessitates the ethnocentric application of the values of one culture onto another. In this 
way, stereotyping creates dichotomous relationships between 'us' and 'them', within which Jacques Derrida (1972) observes, exists a "violent hierarchy" (p. 41) where one group has dominion over the other.

Stereotypical imag(in)ings of Māori have contributed to essentialising discourses which positioned Māori as the racialised Other through elusive representations in the media. It is within this context, Wall $(1995,1997)$ advises, that the stereotype as a 'key mechanism' transmits and replicates racialised discourse. The reproductive power of the stereotype subjects the Other to ideological domination through objectification and categorisation into taxonomies of racial difference (Bhabha, 1983, 1994; Hall, 1992a, 1992b, 1997; Hokowhitu, 2001, 2003, 2004). Here, the power of the stereotype to maintain racialised discourse comes from its ambiguity and ambivalence, resulting in the transpiration of incongruous representations of the Other, which vacillate between mimicry and menace (Bhabha, 1994).

A poignant example of stereotyping is the way in which the so called 'East' is represented by the 'West'. Edward Said (1978) declares that the West is seen as "rational, peaceful, liberal, logical, [and] capable of holding real values" while the Other or East/Orient, in this case, is "none of these things" (p. 49; Kennedy, 2000). Here, Said (1978) is referring to Orientalism: the construction and production of the East/Orient by the West through representations worked in to art, history and language, thereby hegemonically entrenching the West as the author/ity of the Orient (Bolaffi, Bracalenti, Braham, \& Gindro, 2003; Hall, 1992a, 1992b, 1997). Although Said's argument has been criticized, in particular for over essentialising the notions of East and West (Hoeveler \& Cass, 2006), and for misusing the very word 'Orientalism' (Prakash, 1995), it is still a useful means with which to reveal the realities of representation of the Other (Hoeveler \& Cass, 2006). In this article, Orientalism serves as a theoretical platform to analyse the ways in which the Other was 
constructed, simplified and homogenised through representations (Scott, 2008), and indeed as Prakash (1995) notes, Orientalism empowered postcolonial criticisms to analyse Western constructions of Other societies, which serves the nature and purpose of this article.

The West as an idea functions conceptually as well as geographically, and is a historical, rather than a geographical construct, which operates in multiple ways; it provides ideological criteria with which to measure difference, and orders the world in relation to Western standards, making sense of the world by characterising and arranging societies into divergent categories (Hall, 1992a, 1992b, 1997). In its conceptual capacity, the West generates and transmits structures of thought and knowledge in motion, using, as a system of representation, sets of images and statements, which form the basis for perceptions about Other cultures, peoples and societies in contrast to the West (Hall, 1992a, 1992b, 1997). Smith (1999) referring to Hall (1992a) explains that:

...the concept of the West functions in ways which (1) allow 'us' to characterize and classify societies into categories, (2) condense complex images of other societies through a system of representation, (3) provide a standard model of comparison, and (4) provide criteria of evaluation against which other societies can be ranked (p. 42-43).

Stuart Hall (1992a, 1992b, 1997) maintains that the notion of the West was not merely a mirror image of the recognised and traditional Western society, but was fundamental to the very formation of it. He insists that the distinctiveness of the West was in part shaped by Europe's encounters and self-comparison with the Other, and that it was within the context of these interactions that the West was shaped. Overtime and without consideration of their internal differences, Western European nations started to see 
themselves as a homogenous, cohesive assemblage that had one significant thing in common: their difference from the rest of the world (Hall, 1992a).

Foucault (1980) and Hall (1997) emphasise that power is productive. Hall (1997) contends that power generates new objects of knowledge, like the Orient; new forms of knowledge, such as Orientalism; and it influences new practices, like colonisation. Accordingly, there emerged a corpus of knowledge and scholarship about the Orient, created by the West for the West, and in relation to the West. Likewise, Said (1978) upholds that there arose a new object of knowledge produced by the West: “...a complex Orient suitable for study in the academy, for display in the museum, for reconstruction in the colonial office, for theoretical illustration in anthropological, biological, linguistic, racial and historical theses about mankind..." (p. 7-8).

The production of knowledge about the Orient can be understood through what Foucault terms discourse: “...a group of statements which provide a language for talking about - a way of representing the knowledge about - a particular topic at a particular historical moment" (Hall, 1992a, p.291), which subsequently 'colours' our reading(s) of the world and informs our behaviour. The Western authorship and manipulation of Oriental knowledge is, according to Hall (1997), further congruent with Foucault's 'power/knowledge' in that "a discourse produces, through different practices of representation (scholarship, exhibition, literature, painting, etc.), a form of racialized knowledge of the Other (Orientalism) deeply implicated in the operations of power (imperialism)" (p. 260).

Nonetheless, discourse does not operate in isolation, as Lidchi's (1997) Foucauldian analysis proclaims. Rather, discourses transpire in discursive formations which "refers to the systematic operation of several discourses... constituting a 'body of knowledge', which work together to construct a specific object/topic of analysis in a particular way, and to 
limit other ways in which that object/topic may be constituted" (Lidchi, 1997, p. 191). So from this we can see that discourses not only shape the way we see an object/topic, such as the Other, but they also inhibit our minds in such a way that our view of an object/topic remains subject to dominant perceptions. Orientalism, as advocated by Said (1978), is a potent example of the power of discourse, especially in terms of how it vindicated Western authority over the East (Macey, 2000) and continues to fabricate and promulgate inauthentic views of the Eastern-Oriental Other.

Stuart Hall (1997) notes that Said's definition of power relates closely to both Michel Foucault and Antonio Gramsci's ideas around hegemony: the ability or power of the ruling culture to induce the subordinate culture in a way that "appears natural and inevitable" (Hall, 1997, p. 259). Through the power of representation, the Other was positioned as inferior to the West, which occurred in the minds of both the Western observers, and the Other, impacting on the way that the Others came to see themselves (Hall, 1994). Frantz Fanon (1986) sums things up when he states that:

Every colonized people - in other words, every people in whose soul an inferiority complex has been created by the death and burial of its local cultural originality finds itself face to face with the language of the civilising nation... The colonized is elevated above his jungle status in proportion to his adoption of the mother country's cultural standards. He becomes whiter as he renounces his blackness, his jungle (p. 18).

In the Aotearoa New Zealand context Māori were classified as inferior to Pākeha, within a hierarchical racial framework legitimated by both the Judeo-Christian narratives, and adaptations of Darwin's biological determinism (Wall, 1995, 1997). According to Brendan Hokowhitu (2001): 
The construction of race in the European sense was less about cultural differences and more about differences in power. Biological differences only served to justify and confirm the natural power structure in colonialism. Colonisation would have been impossible to justify without discourses of power, race and the right to rule (p. 21).

Congruously, Anne Salmond (1985) argues that historical perceptions of Māori were influenced by evolutionist theories as well as political and economic interests. She states that from:

...the first meeting of Maoris and Europeans, Europeans took the virtue of the imperial enterprise for granted. Aotearoa was on the wild edges of the world, to be 'discovered', named, and tamed by scientific exploration, evangelism, and colonization from the imperial centre (Salmond, 1985, p. 255).

Thus, nineteenth century colonial ideas were inundated with a sense of imperial normalisation (Hokowhitu, 2004), meaning that the colonialists saw themselves as normal and therefore superior, giving them the license to oppress the native Other (Hokowhitu, 2004; Pihama, 2001; Smith, 1999).

Nineteenth century attitudes show that relationships between Māori and Pākeha were a matter of perceived Māori inferiority and Pākeha superiority (Mutu, 2000). The “...racial superiority of Europeans was assumed and the right of colonists to supplant indigenes was justified in the name of progress" (Mulvaney, 1985, cited in Paraha, 1992, p. 8). The settlers believed that their worldview was superior to native perspectives, resulting in the reconstruction of the landscape to suit emerging and evolving colonial-settler identities (Pihama, 1993, 1994, 2001; Smith, 1999). A statement from J. L. Nicholas in 1814 embodies early nineteenth century notions of Māori inferiority: 
Though the savage does possess all the passions of Nature, pure and unadulterated, and though he may in many instances feel stronger and more acutely than the man of civilised habit, still is he inferior to him in every other respect: the former is the slave to the impulse of his will, the latter has learned to restrain his desires; the former stands enveloped in the dark clouds of ignorance, the latter goes forth in the bright sunshine of knowledge... (cited in Salmond, 1985, p. 255).

While two famous statements from Newman (1881) and Featherstone (1881), given when Māori were thought to be a 'dying race', also demonstrate later nineteenth century attitudes:

Taking all things into consideration, the disappearance of the race is scarcely subject for much regret. They are dying out in a quick, easy way, and are being supplanted by a superior race (Newman, 1881, cited in Buck, 1924, p. 362).

The Maoris are dying out, and nothing can save them. Our plain duty, as good, compassionate colonists, is to smooth down their dying pillow. The history will have nothing to reproach us with (Featherstone, 1881, cited in Buck, 1924, p. 362).

\section{Discourses of the 'Māori Other'}

Western representations of the corporeal Other were used to justify colonial activities: "the dominant discourse presented a tale of pioneering hardship, underscored by the self-predicating "white man's burden" - to conquer the world, civilise it and then to provide enlightened leadership into the twentieth century" (Hokowhitu, 2003, p. 28). So, it was believed that Māori people needed colonisation and industry (Mutu, 2000; Petrie, 1998, 2006; Simon, 1990; Smith, 1999) for their "spiritual and economic salvation" (Petrie, 1998, p. 9). The white man's burden was to cleanse, assimilate and civilise 
the Other (Hall, 1997; Hokowhitu, 2003, 2004; McClintock, 1995; Petrie, 1998, 2006; Simon, 1991), but the burden was 'his' alone, for ostensibly, only white men had the strength and resilience, the intelligence and the aptitude to carry out the humanistic task of en-lightening the dark corners of the globe (Hokowhitu, 2004). According to Linda Smith (1997):

As Maori, we have been defined in terms of our difference to our colonisers. ...the way Other has been historically structured has denied us our own ways of defining and relating to differences. In creating a 'new' nation, the colonisers placed great emphasis on how different they were from (and much 'better' than) the native inhabitants. The emphasis [was] placed on the constructed dualisms of savage and civilised, heathen and Christian, immoral and moral (p. 33).

Since Māori, like other colonised peoples, lacked the features of 'proper civilisation' such as Christianity, law, government, farming and European work ethic, the settlers saw Māori as uncivilised and savage (Mutu, 2000; Petrie, 1998, 2006; Weaver, 2009). Brendan Hokowhitu (2001) examines the discourse around the Māori Other and argues that discourse around the Māori Other oscillates around the binary signifiers of savage and civilised. He states that the colonisers:

...demanded historical representations of the Others living in pre-philosophical dream-worlds. Historians, philosophers, biologists and anthropologists subsequently built a universal or global picture of the primitive Other. The breadth of consistent representations gave reliability, the scope of peoples covered gave generalisability, and the divinity of objective science gave validity (Hokowhitu, 2001, p. 24).

In Hokowhitu's analysis, the Māori Other is explored within six themes, Māori as: animalistic, barbaric, 
physical/unintelligent, mythical, bewildered, and noble. These themes are common throughout the literature, as a statement from Anne Salmond (1985), regarding populist theories of nineteenth century New Zealand shows:

...'savages' and 'barbarians' were held to be like children, like ancestors (ancient Britons, Israelites, or Aryans in the Maori case), or like beasts to be tamed, exterminated, documented, or educated, according to the political philosophy of the writer. In all theories they were lesser beings, whose destiny could only be decided by 'civilised men' (p. 256).

Here, the six categories of Māori as Other, explained by Hokowhitu $(2001,2003,2004)$, is used here to organise the literature as a means to identify how these views provided the rationale used and developed by the colonists, to part Māori from their land.

\section{Māori as 'Animal' Other}

In the nineteenth century Māori were perceived and represented as being animal-like, violent and savage (Hokowhitu, 2001, 2003, 2004), particularly during New Zealand's civil war (Belich, 1988). The view that Māori were seen as animal-like is consistent with Smith's (1999) argument that Māori (as Indigenous people) were seen as being less than fully human:

The European powers had by the nineteenth century already established systems of rule and forms of social relations which governed interaction with the Indigenous peoples being colonized. These relations were gendered, hierarchical and supported by rules, some explicit and others masked or hidden. The principle of 'humanity' was one way in which the implicit or hidden rules could be shaped. To consider Indigenous peoples as not fully human, or not human at all, 
enabled distance to be maintained and justified various policies of either extermination or domestication (p. 26).

These views were also reflected in colonial literature which constructed a sexualised, animalesque, mythic, pre-historic image of the Māori savage (Hokowhitu, 2001, 2003, 2004; McNaughton, 2004; Nicole, 2001; Wall, 1995, 1997). Talia McNaughton (2004) states that:

This characterisation of the savage in New Zealand was depicted in colonial literature, and the children's literature of the time, cementing the image of a wild, beast-like people, far removed from the mother country. This fictional depiction of Māori occurred in order to reinforce the colonisation process (p.18-9).

The various arguments which demonstrate that Māori were perceived as animal-like and lower on the evolutionary ladder not only justified colonialism, but desensitised the settlers to colonial violence (Hokowhitu, 2001). Māori were seen as "half human, half beast" (Giddens, 1993, cited in Hokowhitu, 2001, p. 44), physically agile “... as readily as monkeys" (Wade, 1977, p. 157), primate-like in that "[n]othing can remind one more forcibly of the monkey who has seen the world, than a Maori thus relating the news" (Wakefield, 1845, cited in Best, 1925, p. 120), and that the haka, a traditional 'dance of a noble people' (Karetu, 1993), looked as though it was performed by "mad-monkeys" (Maning, 1956, cited in Hokowhitu, 2001, p. 44). Polack (1840) notes, in relation to haka, that "The tongues of the performers were thrust out of their mouths, with an extension that rivalled the well-known chameleon" (p. 88).

\section{Māori as Savage-Barbarian Other}

Decontextualised accounts of Māori and Pākeha interactions substantiated the alleged barbarism and inferiority of Māori (Hokowhitu, 
2001). Within the coloniser/colonised binary, the savage Other was "...an allegorical figure that represents what the civilised Self is not" (Hokowhitu, 2003, p. 21), a dark-skinned brute "encumbered by his inability to evolve, ruled by his passions, physical, immoral, and sinful" (Hokowhitu, 2004, p. 265). Fanon (1963) illustrates the coloniser's depiction of the 'native' in this way:

...the settler paints the native as a sort of quintessence of evil... The native is declared insensible to ethics; he represents not only the absence of values, but also the negation of values... he is the enemy of values... in this sense he is the absolute evil... the corrosive element... the deforming element... the depository of maleficent powers... (p.41).

This is congruent with Smith's (1999) statement in relation to Christianity, that Māori were seen as 'fallen souls' in need of salvation from their heathenistic, savage and barbaric ways:

For the missionaries there was a huge and exciting minefield of lost and fallen souls who needed rescuing. The savagery, abhorrence and 'despicability' of the natives challenged their very vocabulary... The more horrendous and evil the people, the stronger the imperative was to carry out God's work (p. 78-9).

A statement from Donald McLean (1861) shows some of the terms used in the nineteenth century to describe the savage Māori Other, while an excerpt from The Wellington Independent (1868) embodies the intensity of colonial domination:

The offensive terms "bloody Maori", "black nigger", "treacherous savage" are frequently applied to them; 
and, though uniformly kind and hospitable to all strangers, they are themselves often treated with cold indifference, and sometimes with contempt, when they visit the English towns (cited in Mutu, 2000).

We must smite, and spare not... they are determined to fight, and we, in self protection must treat them as a species of savage beasts which must be exterminated to render the colonisation of New Zealand possible (The Wellington Independent, July 21, 1868, cited in Rusden, 2000 [1888], p. 108).

Within the Christianising context of nineteenth century Aotearoa New Zealand, the haka was particularly damning as accounts of its ferocity were interpreted through the white gaze. As such, the haka was seen as "demonical", "distorted", and "diabolical [in] appearance" (Polack, 1840, p. 86-87), while the facial expressions were "confined to such epithets as 'grotesque, 'savage', and 'indecent"' (Karetu, 1993, p. 29). Regarding the haka, accounts from Edgar (1786) and Earle (1909) are significant:

The War dance... consists of a variety of violent motions and hideous contortions of the limbs, there is something in them so uncommonly savage and terrible, their eyes appear to be starting from their head, their tongue hanging down to their chin (Edgar, 1786, cited in Hokowhitu, 2001, p. 46).

...they soon work themselves up to a pitch of frenzy; the distortions of their face and body are truly dreadful, and fill the mind with horror (Earle, 1909, cited in Hokowhitu, 2001, p. 46).

\section{Māori as Physical-Unintelligent Other}

Following on from the guttural utterances and distorted gyrations of the haka, was the essentialising perception that Māori were physical and therefore unintelligent. Here physicality was linked to the intellect in a way which 
discredited Māori intelligence and knowledge; this was used as a mode of oppression to construct Māori as intellectually inferior (Hokowhitu, 2001). Darwinian and other evolutionary theories, circuitously yet significantly contributed to the skewed recordings and consequent Othering discourses of nineteenth century Aotearoa New Zealand (Hokowhitu, 2001; Simon, 1990; Wall, 1995, 1997). Anne Salmond (1985) notes that intellectual evolutionism was/is “...a potent colonial ideology in Aotearoa, ratifying political inequalities and disclaiming Maori knowledge by a complete epistemological prejudgement" (p. 257). She argues that evolutionary ideology became increasingly brutal as the thirst for land intensified. At the time of the Land Wars, the following 1861 statement from the House of Representatives illustrates the discursive violence towards Māori:

The [Māori] Race, it is said, is irredeemably savage. It is moribund. All that is wise, or safe to attempt, is to pacify or amuse them until they die out, - until the inscrutable physical law amongst them shall relieve the country from the incubus of a barbarous population, or... render it practicable to reduce them to the condition for which nature has intended them, of hewers of wood and drawers of water (AJHR 1861 EI: 4-5, cited in Salmond, 1985, p. 257).

Furthermore, a statement from Arthur S. Thomson (1859) asserts that: "The New Zealanders [Māori] hold the head as extremely sacred, but they do not suppose it contains the sole intellectual organ; as joy, fear, and sorrow, spring, according to their notions, from the stomach and bowels" ( $p$. 81). Herein, and in his statement to follow, Thomson, using a Western medical critique, addresses and concretizes Māori intelligence at the level of the body:

It was ascertained by weighing the quantity of millet seeds skulls contained and by measurements with tapes and compasses, that New Zealanders [Māori] heads are smaller than the heads of Englishmen, consequently the New Zealanders are inferior to the 
English in mental capacity.... This analysis shows that the New Zealanders have the minds of children (p. 814).

\section{Māori as Mythical Other}

Implicated in the idea that Māori were unintelligent, is the colonial belief that Māori knowledge was inferior and mythical (Hokowhitu, 2001; Johnston, 1998, 2010). The positioning of Māori knowledge as myth, fable and ancient tradition, locates it in the pre-civilised past (Hokowhitu, 2001; Smith, 1999) as "primitive, pagan and inferior" (Raerino, 1999, p. 27). Constructed as not fully human, Māori were seen as incapable of creating history, and so Māori knowledge and culture was deemed to be prehistoric (Smith, 1999). This is consistent with Hokowhitu's (2001) assertion that nineteenth century and early twentieth century writers such as Dieffenbach, Best, and Anderson hypocritically labelled Māori as uncultured because of the perception that Māori knowledge was composed of stories and myth, regardless of their own cultures' employment of narratives to illustrate European worldviews. Consider, for example, the biblical creation story, or King Arthur and the Holy Grail.

\section{Māori as Bewildered-Child-Like Other}

Europeans saw Māori behaviour as contradictory and therefore confused, bewildered, and child-like, meaning that Māori were in need of humanistic civilising and Christianising for their own good (Hokowhitu, 2001). It was of course necessary to represent Māori as immature to justify colonisation and to demonstrate that Māori, like their Polynesian cousins were "...only big, grown-up children" (Hall \& Osborne, 1901, cited in Tamplin, 1992, p. 70). Consistently, Buick (1914) states that Māori “...is in a state of pupilage, and must be treated as we treat children" (cited in Salmond, 1985, p. 256). The idea of Māori immaturity was supported by 
writers who claimed that Māori lived in a fairy tale world (Schwimmer, 1966), and that Māori, like children, lacked substance and intellectual depth (Hokowhitu, 2001).

\section{Māori as Romanticised 'Noble' Other}

Linda Smith (1999) claims that the romanticisation of the South Pacific originated with Rousseau, who posited that the Indigenous inhabitants therein were 'noble savages' in that their links to the natural world demonstrated their 'innocence and purity', qualities he believed were lost to the West. Notwithstanding the dominant discourse of the savage Other, some like Rousseau, believed that the Indigenous Pacific possessed moral superiority on account of their natural attributes and connections (Hokowhitu, 2001). The "corruption and decay" of the 'developed' world stood in stark contrast to the seemingly care-free Pacific islands (Smith, 1999, p. 49). Indeed, Māori were seen as 'better blacks' than others for they were supposedly easier to civilise and Europeanise than others (Belich, 2001).

Scattered throughout nineteenth century literature and embedded within the impression of a care-free Pacific, is the construction of the idle savage which represented Māori, Pacific and other Indigenous peoples as lazy due to the absence of European pursuits, industries and past-times (Petrie, 1998, 2006). Colonial beliefs about work and progress contributed to ideas of racial difference, which informed Pākeha perceptions and representations of Māori as lazy (Petrie, 1998, 2006).

\section{Race and Land Loss}

Ideological power over the Other, and material exploitation of Aotearoa New Zealand, was vindicated by racial representations and stereotypes (Wall, 1995, 1997) which proposed that Māori were intellectually and culturally inferior, 
and therefore undeserving of their land (Mutu, 2000; MacDonald, 1990, cited in Mutu, 2000). This confirms Dalal's (2002) assertion that the construction of the Indigenous Other defended and facilitated the process of colonisation. Paul Spoonley (1996) maintains that the very act of colonisation was a historical process which racialised Māori as individually, collectively and culturally inferior, legitimating colonial acts of cultural suppression, and (un)lawful land acquisition. According to Simon (1990):

...Pakeha dominance was secured during the first fifty years of colonization by a combination of processes largely rationalized through the ideologies of 'race' and sanctioned by British law. These included the largescale alienation of Maori land, the establishing of the capitalist mode of production and an immigration policy that favoured only British and other West Europeans. This situation, however, was not arrived at without considerable resistance and struggle on the part of the Maori (p. 1).

Pākeha oppressed Māori and claimed, re-named and inscribed their colonial identity onto the landscape to make it theirs. Western constructs were superimposed over Māori ways of knowing to subjugate, colonise and ultimately to alienate Māori from their land - the source of Māori identity, historically, socially, politically and geographically (Mutu, 2000; Pihama, 1993, 1994; Smith, 1999). A statement from MacDonald (1990) reveals the level of ideological Eurocentrism and cultural superiority which underpinned Pākeha views of Māori in colonial history:

For much of New Zealand's colonial and post-colonial history the Pakeha cherished an image of Maori as a genial buffoon, an improvident fellow who deserved to lose his land and who was unlikely to make good use of it if he got it back again. This caricature suited the European New Zealander... (p. 7). 
Albert Memmi (1990) states that "[n]othing could better justify the colonizer's privileged position than his industry, and nothing could better justify the colonized's destitution than his indolence" (p. 145). This was undoubtedly the case in Aotearoa New Zealand, where the dominant ideas around Māori and land in the nineteenth century, centred on the perception that Māori were intrinsically lazy (Petrie, 1998, 2006). But while Māori certainly were not idle, their communal work ethic - based on pre-industrial work patterns such as hunting, fishing and agriculture, called 'task orientation' by Thompson (1967) - was considered uncivilised and immoral by some, like Samuel Marsden for example, who believed that Māori needed to be taught about industry (Petrie, 1998, 2006). Hence, it was believed that Māori merely squatted on their land and wasted its potential. But what the coloniser saw as wasteland, had always been attributed with abundance and sustenance by Indigenous peoples (Friedberg, 2000). Hazel Petrie (1998) states that:

One of the most damaging aspects of the 'lazy Maori' stereotype has been its role in the alienation of Maori land. In this connection, it was modified to incorporate not only laziness and improvidence, but procrastination and the obstruction of 'progress' (p. 30).

Essentialising characteristics commonly attributed to nomadic peoples by Victorian ethnologists, and also to London's poor in Henry Mayhew's (1812-1887) mid nineteenth century study, which polarised the 'civilised' and 'uncivilised' of London as 'races' (Mayhew, [1861]1968), were also allocated to Māori: "a repugnance to regular and continuous labour; a want of providence; a love of gambling and 'stupefying substances' such as alcohol; cruelty and warlike tendencies; libidinous behaviour and an absence of chastity among women" (Petrie, 1998, p. 9). Conversely, Harold Miller (1966) notes that "The [Māori] people were industrious, engaged for 
nine or ten months of each year in digging and planting and weaving and building..." (p. xii), which counters, somewhat, the allegation of inherent laziness.

The Land Court system would facilitate Pākeha desires to rid the 'lazy' Māori people of their 'wasted' land. A member of parliament commented in 1885 :

I believe we could not find a more ingenious method of destroying the whole Maori race than by these Courts. The Natives come from the villages of the interior, and have to hang about for months in our centres of population .... They are brought into contact with the lowest classes of society, and are exposed to temptation and the result is a great number contract diseases and die .... Some little time ago I was taking a ride through the interior and I was perfectly astonished at hearing that a subject of conversation at each hapu I visited was the number of natives dying in consequence of attendance at the Native Land Court at Wanganui (NZPD 1885, volume 52, p. 515, cited in The Pouakani Report, 1993, Waitangi Tribunal online).

And an 1870 parliamentary comment from Henry Sewell highlights the purpose behind the Native Lands Act:

The object of the Native Lands Act [1865] was twofold: to bring the great bulk of the lands of the Northern Island which belonged to the natives ... within the reach of colonisation. The other great object was, the detribalisation of the natives - to destroy if it were possible, the principle of communism which ran through the whole of their institutions, upon which the social system was based, and which stood as a barrier in the way of all attempts to amalgamate the Native race into our own social and political system. It was hoped that by the individualisation of titles to land, giving them the same individual ownership which we ourselves possessed, their social status would become assimilated to our own (NZPD, 1870, volume 9, p. 361, cited in The Pouakani Report, 1993, Waitangi Tribunal online). 


\section{Historical Context: Setting the Scene for the Displacement and Relocation of Patuheuheu and Ngāti Haka}

Māori connections to land are pivotal to Māori identity. However, the state interrupted these connections by claiming a pre-emptive right to supposedly un-utilised lands using the Treaty of Waitangi (Cheater \& Hopa, 1997; Orange, 1987; Walker, 1990). The state launched an assault on Māori who refused to sell their land and by 1900 the relatively new state had acquired, legally and otherwise, over ninety percent of the country for the state and its settler populace (Cheater \& Hopa, 1997; Walker, 1990). According to Angela Ballara (1996):

...[T]he Crown became a vigorous and monopolistic purchaser, buying land in ways that caused division in Maori society. At first open meetings had discussed land purchases, but from the late 1840s land was often bought secretly by government officials or without proper enquiry into its ownership, from Maori individuals or groups who did not represent all the owners. Before colonisation these sellers would not have had the right to gift land, let alone alienate it (p. 4).

Ever since the land wars of 1845-1872, issues around confiscated lands became a site of political discontent (Belich, 1986). Within Pākeha and Māori communities in the 1880s and 1890s, debates around the control, distribution and use of land were paramount (Brooking, 1996). This was demonstrated by the sheer volume of land legislation passed, the large spaces available in newspapers dedicated to land issues, and the arguments over land recorded in parliament (Brooking, 1996). Pākeha greed is blamed by some as the principal motivator for land grabbing manoeuvres (see Awatere, 1984; Walker, 1990), but in other accounts the settlers came to Aotearoa New Zealand, in part, to escape the effects of the urban and industrial revolution; most were 
desperate to own land, which in itself increased the chances for upward social mobility (Brooking, 1985, 1996; Erikson, 1972; Fairburn, 1979, 1989), while life in cities was considered by the settlers to be inferior to life in the countryside (Brooking, 1996).

Settlers wanted land for self-improvement, a more organic way of life, and to separate themselves from the clutches of landlords, clergy, and bailiffs (Brooking, 1996; Erikson, 1972; Fairburn, 1989). The settlers envisioned a better society, and believed in reshaping the land to provide for this 'improvement' (Brooking, 1996). The colonial Government employed legislation, based on nineteenth century English law and notions of capitalist patriarchy, to serve Pākeha interests (Kelsey, 1984; Wiri, 2001) and replace Māori law with Pākeha law (Sykes, 2006; Woodward, 2008). The land court was set up to take Māori land, and was a destructive vehicle used for Pākeha land acquisition, which further reconceptualised notions of whenua, introduced the idea of ownership, sought the individualisation of land titles, and disseminated Western ideas of individualism: that is, the commodification of land, and the construction of human beings as autonomous, enterprising economic agents in a so called free market (Graham, 1990, 2003; Kawharu, 1977; Macpherson, 1962, cited in Graham, 2003; Mutu, 2000; Smith, 1999; Walker, 1990; Woodward, 2008).

\section{Patuheuheu and Ngāti Haka Land Loss}

As with other Māori in the nineteenth century, Patuheuheu and Ngāti Haka were subjected to the dominant discourses of racism which justified Pākeha getting hold of land using whatever methods necessary. Patuheuheu and Ngāti Haka were imprisoned for two years, and then after their release, their land at Te Houhi, located in affluent modern-day Galatea, was acquired by fraud. Eviction from their homes followed. These events are a sore point for Patuheuheu and 
Ngāti Haka and continue to give the people the impetus to move towards restitution. The following gives an overview of these events.

\section{Capture and Imprisonment for Patuheuheu and Ngāti Haka}

In the nineteenth century, Patuheuheu and Ngāti Haka principally occupied the Te Houhi, Waiohau and Horomanga areas (Binney, 2009a). In 1870, because of their association with Te Kooti - a nineteenth century Māori leader, prophet and revolutionary whom the government wanted to get rid of Patuheuheu and Ngāti Haka were deemed by the government to be rebels, and were consequently captured and removed from their homes in the Horomanga and Waiohau valleys (Binney, 2001a, 2002, 2003; Paul, 1995; Pouwhare, 2004). According to Linda Smith (1999) "[s]ome Indigenous peoples ('not [seen as] human'), were hunted and killed like vermin, others ([seen as] 'partially human), were rounded up and put in reserves like creatures to be broken in, branded and put to work" (p. 26). Likewise, Patuheuheu and Ngāti Haka were 'rounded up' and relocated to the government reserve of Te Putere on the Bay of Plenty coast (Binney, 2001a, 2002, 2003; Paul, 1995; Pouwhare, 2004) which Binney (2003) describes as being akin to a concentration camp:

I used the term 'concentration' camp because people were 'concentrated' there. ...George Preece... stated [in September 1870]...that, 'The prisoners now at Te Putere are badly off for food.' In 1872, he noted that their crops had failed every year since 1870 . He also stated that the land was...very poor...

Everyone agreed it was bad land, situated amongst sand dunes, and unsuitable for cultivation. It was a 'concentration camp' for people who were forced to live largely on government handouts of potatoes until they went home in 1872-73 (p. 2-3). 
In 1872-73 Patuheuheu and Ngāti Haka were released and returned to their lands at Te Houhi which became their main kainga settlement (Arapere, 2002; Binney, 2001a, 2002, 2003, 2009a; Paul, 1995). The people established their home there, and by some accounts, this was also the site where the wharenui, Tama-ki-Hikurangi, was built in 1904 (Binney, 1995, 2001; Neich, 1993). Te Houhi School was opened much earlier on 28 November 1893, with Mēhaka Tokopounamu as the first school chairman (Binney, 2002). With their homes, a wharenui and a school in place, the community of Te Houhi would have seemed stable and secure, especially when compared to the awful conditions endured at Te Putere. However, the 1880 s and 1890 s would prove to be another time of sheer uncertainty for the people of Patuheuheu and Ngāti Haka. It would be a time when colonial maps demarcating the land would be redrawn yet again. A devastating act of fraud was on the horizon and Patuheuheu and Ngāti Haka's home and way of life was at definite risk once more. Harry Burt, a licensed Native Land Court interpreter and ostensible friend of the prophet Te Kooti orchestrated fraudulent land transactions in the mid-1880s that would ultimately lead to the displacement of Patuheuheu and Ngāti Haka from their land at Te Houhi (Binney, 1997, 2001, 2002; Boast, 2008).

\section{Harry Burt the 'Thieving Ghost'}

Judith Binney (2001a) contends that Burt belonged to a "'sub-culture': a visible group of early settled Pakeha men who lived with Maori women" (p. 162) and spoke the native language. Harry Burt, or 'Hare Paati' as he was also known, was a trickster who hid behind a cloak of colonial hybridity (Binney, 1997, 2001). Burt "claimed friendship and more kinship - with Maori... He was a manipulator, who created a mood and experience of confidence and trust. He was a 
swindler who outmanoeuvred a prophet" (Binney, 2001a, p. 148).

Binney's (2001a) idea of colonial hybridity presents an interesting picture of the ways in which some Pākeha slotted into Māori communities and indeed, into Māori life. Although, in Harry Burt's case this hybridity extended not only to living with the people and inhabiting their space, but also to fraudulently claiming whakapapa and whenua. Bentley (1999) claims that some Pākeha "penetrated Maori communities, adapted to tribal life and influenced their hosts" (p. 9). Harry Burt did all of these things to the utter detriment of Patuheuheu and Ngāti Haka. Binney's notion of colonial hybridity is congruent with Robert Pouwhare's (2004) conception of Harry Burt:

Even though he was a Pakeha his common name amongst us was Hare Paati. Many mistook his [sic] for Maori. He spoke fluent Maori, he was an interpreter for the Native Land Court. We heard he was a Maori from Ngati Raukawa, but one of his names was Hare Rauparaha and he also said he was from Ngati Toa.

He also took to wife the daughter of the Chief Wi Patene Tarahanga, but the old women knew it was calculated so he could inveigle himself into her heart and into her thighs, (that is the old peoples [sic] words) (p. 38).

Harry Burt is described as a 'thieving ghost'; a fraudster who used the mind altering power of alcohol to cheat the people; and a deceitful liar who seduced two Ngāti Manawa owners with money and spirits to steal Patuheuheu and Ngāti Haka's land (Pouwhare, 2004). These two men may also have had genealogical links to Patuheuheu and Ngāti Haka (R. Pouwhare, 2009, personal communication), but because of their acts were forced to leave Te Houhi in shame (Pouwhare, 1996).

The block of land on which Te Houhi was located was known in the Native Land Court in 1878 as Waiohau 1 
(Arapere, 2002; Binney, 2001a, 2002; Paul, 1995). In January 1886, a committee of twelve Tūhoe men, joined by Te Kooti, met with Burt to negotiate; they asked him to accept 1,000 acres of land to satisfy his needs, but Waiohau 1 was illegally brought before the Court for partition by 'Hare Rauparaha', one of Burt's pseudonyms (Binney, 2001a, 2002, 2007a). Burt abused his position as an interpreter in the Native Land Court and invented a new identity by stealing whakapapa and prestige from the name of the famous Ngāti Toa chief, Te Rauparaha (Binney, 2001a, 2007a). The partition was to establish half of the block, 7,000 acres, as Waiohau 1B in the name of two Ngāti Manawa owners, Pani Te Hura (Peraniko Ahuriri) and Hira Te Mumuhu (Binney 2001a, 2002, 2007a). According to the Reverend Hieke Tupe, these Ngāti Manawa owners had been included in the 1878 title of Waiohau 1 “...through aroha” (Binney, 2001, p. 158; Binney, 2002; Paul, 1995). These men immediately sold the newly established Waiohau 1B to Harry Burt in the Court foyer witnessed by Judge H. T. Clarke (Binney, 2001a, 2002).

Burt's deceitful acts were examined in a judicial inquiry in 1889 , recommended by Parliament, in response to a petition from Mēhaka Tokopounamu, a chief of Te Houhi (Binney, 2001a). The petition was put forward by Mēhaka Tokopounamu and 86 others in 1888 to the Native Minister (Binney, 2001a, 2002; Paul, 1995). The petition claimed that Harry Burt had fraudulently acquired ownership of Waiohau 1B by coercing people to sell their shares to him (Binney, 2001a, 2002; Paul, 1995). Burt's actions included taking the signatures of minors, acquiring shares from those who did not own them, purchasing without witnesses, purchasing the shares of deceased persons, getting people drunk and then getting them to sign over their shares, and finally by giving guns and gun powder (Paul, 1995).

On 13 August 1889, a year after Mēhaka Tokopounamu's petition was sent to the Native Affairs Committee, it was finally heard (Paul, 1995). The petition gives 
information about the subdivision of the Waiohau block and then claims that:

1. The said land was divided while we were absent. Apportioning the part that the European had bought and the part that we were to receive.

2. There was no person there to conduct matters on our behalf in dealing with the said land, save but three natives who by mere chance appeared at the Court, who without any authority took upon themselves to conduct matters on our behalf while we were ignorant of the same.

3. There were 7000 acres set apart for Mr. Burt, although he only bought 40 persons shares, and the remainder were set apart for the whole tribe.

4. We the people who did not dispose of their shares and who have been living on the land for several years have lost all their land and places of abode and their fences and their cultivations (that is) they have all passed or been set aside for that European (Mēhaka Tokopounamu's petition, 1888, cited in Paul, 1995, p. 15).

The judicial inquiry found that the Native Land Court's partition order was based on proof given by Māori who were manipulated by Burt (Binney, 2001a; Paul, 1995). The inquiry was then referred to Judge Wilson who in 1889 after a lengthy investigation - including claims and counter-claims between Patuheuheu and Ngāti Haka, their leaders Wi Patene and Mēhaka Tokopounamu, Ngāti Manawa's leaders and Harry Burt - found that "Burt behaved fairly toward the natives in the matter of this purchase until they turned against him and placed themselves under the guidance of Te Kooti" (Paul, 1995, p. 29).

\section{Eviction from Te Houhi}


Patuheuheu and Ngāti Haka were absolutely impoverished by the onslaught of Court battles that were endured over the land. The people of Te Houhi had been marginalised and victimised by an oppressive Pākeha system which took away from them their land, their home, their identity, and their view of their sacred mountain, Hikurangi. Furthermore, even after the people had exhausted every resource to fund the ongoing legal battles, the Courts recognised that the people of Te Houhi had been severely wronged but were unwilling to help:

I regret the hardship to the defendants. That they have suffered a grievous wrong is, in my opinion, plain. It is doubly hard that this wrong should have resulted from a miscarriage, which certainly ought to have been avoided, in the very Court which was specially charged with the duty of protecting them in such matters. The plaintiff [Margaret Beale] is, of course, blameless in the matter (cited in Binney, 2001a, p. 151, [Beale v Tihema Te Hau at 891]).

These Court proceedings eventually led to Te Houhi falling into the hands of one Mr. James Grant (Binney, 2001a). The people had been advised in 1890 by their lawyer Mr. Howorth that maintaining peaceful and continued occupation of their land would be enough to ensure ownership (Binney, 2002). Patuheuheu and Ngāti Haka had "...made up their [mind]s not to be ejected [exc]ept by force" (Pope, 1895, cited in Binney, 2002, p. 327). A letter printed in the Hot Lakes Chronicle, 11 November, 1905 states that:

...there is an amazing appeal to the white man's ignorance and cowardice. The settlers are fearful of results, when everybody who knows these Maories [sic] are aware that they are as law abiding and peaceable as any that exist.

What kind of a country is [this] that we live in if such things as these can be done amongst us without an 
immediate and effectual protest? Is it "God's own" or the "Devil's own"?

Those who travel as far as Galatea just now may see what they would not see anywhere else in the world, a solicitor with sheriff and bailiffs using physical force to gain possession of the land and dwellings of the whole settlement of families whose property has, by the public acknowledgement of the Judge of the Supreme Court, been stolen from them without any fault of theirs (cited in Wouden, 1980, p. 13-15).

In spite of Patuheuheu and Ngāti Haka's protests, once Grant took official ownership of the land in February 1907, he made it difficult for the people to stay by destroying their cultivations; he eventually evicted the people in the winter of 1907 (Binney, 2001a, 2007a; Boast, 2002; Wylie, 1908, cited in Wouden, 1980). Richard Boast (2002) states that:

The mean-spirited and vindictive James Grant, a local landholder who was apparently driving the entire process, ensured that the eviction process was as complete and demeaning as possible, even preventing them from taking their school house and wharenui from the land (p. 156).

As well as the school house, Patuheuheu and Ngāti Haka had to leave behind their beloved wharenui, their church, and the sacred remains of their dead (Binney, 2001a). James Grant used the wharenui as a hay barn and the school house as quarters for his farm workers (Binney, 2001a 2002). According to some narratives, the government purchased the wharenui back from Grant for Patuheuheu and Ngāti Haka for $£ 140$ in 1908 (Binney, 2001a; Boast, 2002; Paul, 1995). While some local stories insist that Patuheuheu and Ngāti Haka had to pay Grant for the wharenui themselves. Regardless of the variations in events, the people removed and relocated the wharenui by wagon piece by piece, refusing all assistance, except for a $\$ 40$ grant from the government to purchase much 
needed food (Binney, 2001a). Again, local oral accounts present a slight deviation, in that some believe that the wharenui was transported on the Rangitaiki river, perhaps, as well as by wagon. The wharenui was re-opened at Waiohau on 28 July 1909 (Binney, 2001a; Paul, 1995).

The 1885 Land Transfer Act was particularly damaging to Patuheuheu and Ngāti Haka regarding their Te Houhi land. After the land had been sold from underneath them, Patuheuheu and Ngāti Haka pleaded with the government to overturn the new titles to Te Houhi in order for their land to be returned (Binney, 2001a). This request fell on deaf ears. Although the 1889 judicial inquiry by Judge Wilson clearly showed that the people of Patuheuheu and Ngāti Haka had been wronged, the government refused to overturn the titles based on the 1885 Land Transfer Act which protected Pākeha not Māori. Furthermore, Binney (2001a) notes that unusually in British legal practice, the Land Transfer Act did not have a time allowance after the land 'changed hands' for the owners to dispute the transfer.

\section{Conclusion}

It has been shown that race is both an inauthentic measurement of human difference, and a meaningful social category in terms of the perceived differences between the races. It is evident from the literature that racial discourses have informed racial practices with regards to the ideological and hegemonic construction of representations and stereotypes through which the Other was objectified and oppressed, in ways which privileged whiteness. This article has also demonstrated that in the Aotearoa New Zealand context, negative racial representation and stereotyping influenced Pākeha mainstream media and literature, forming Othering discourses about Māori (Jones, 1998; McNaughton, 2004; Petrie, 1998, 2006; Wall, 1995, 1997), meaning that Māori were subjected to structural barriers which inhibited 
their development politically, socially and economically in the nineteenth century and beyond.

Ideas about race and difference were used by the colonisers to inform and justify oppressive frameworks and practices which made it easy for Pākeha to acquire land by legal or illegal means, while the Pākeha legal system made it difficult and in many cases impossible for Māori to fight back. Indeed, the application of racial discourse in the Aotearoa New Zealand setting, and the constructions of the Māori Other were used by Pākeha to create an image that Māori were inferior in every way and therefore did not deserve to own land. The way that the colonists were able to create these images is similar to the way that Said (1978) explains Orientalism. Drawing on the notion of Orientalism as a Western way of constructing and authoring of the Orient through language, history, writing, and art (Bolaffi, Bracalenti, Braham, \& Gindro, 2003; Hall, 1992a, 1992b, 1997), the term 'Māorientalism' could be used here to denote the way in which the colonists did the same to Māori.

While referring to Said's work, Atareta Poananga (1994) contests that Orientalism ensured the West was perceived as superior by training Indigenous/Māori people to uphold Western worldviews within their own Indigenous worlds, thus maintaining the West's positional superiority. Pākeha representations of Māori operated to the benefit of the coloniser and to the detriment of Māori, given that Māori images and knowledge were destabilised and undermined by Pākeha for the purposes of colonisation (Johnston, 2001). Poananga (1994) further contextualises Orientalism into an Indigenous-Pacific milieu when she states that: "Not only did the West construct the non-western according to its own cultural dictates, it also deconstructed and then reconstructed the indigenous universe" (p. 2). She insists that Orientalism moved beyond the borders of the East, with the colonising gaze fixed firmly on the islands of the Pacific.

Patuheuheu and Ngāti Haka, like all Māori, were seen as inferior by Pākeha, which is demonstrated by the 
underhanded ways in which their land was taken from them by Harry Burt, and by the way they were treated by James Grant who came to own the land where their homes were built. It is clear that the effects of colonisation have been far reaching for Māori which is evident in New Zealand's history. This article has demonstrated that the people of Te Houhi have been marginalised and victimised by an oppressive Pākeha system which took away their land while they continue to live in poverty to this day. This pattern of disadvantage is discernible from the signing of the Treaty of Waitangi in 1840, as Māori have been politically and culturally marginalised and constructed as Other (Bishop \& Glynn, 1999; Bishop \& Berryman; Hokowhitu, 2001, 2003, 2004; Johnston, 1998, 2010; Smith, 1999; Thomas \& Nikora, 1996; Walker, 1990). Significantly, the actions of Harry Burt and the Crown were supported by views about race, embedded within the political and legal systems, which were set up by Pākeha and thus served Pākeha interests, satisfying settler demands for land (Simon, 1990). With regards to the signing of the Treaty of Waitangi and the consequent land loss that followed, Nopera Panakareao stated that "...the shadow of the land will go to him (the Governor) but the substance will remain with us" (cited in Thomas \& Nikora, 1996), which relates to how Patuheuheu and Ngāti Haka still connect to the substance of the land they lost at Te Houhi.

\section{Bibliography}

Abercrombie, N., Hill, S. \& Turner, B.S. (2006). The penguin dictionary of sociology. Auckland: Penguin Books.

Allen, M. (2009). An illusory power? Metropole, colony and land confiscation in New

Zealand, 1863-1865. In R. Boast \& R. S. Hill (Eds.). Raupatu: The confiscation of Maori land (pp. 110-139). Wellington: Victoria University Press.

Anon. (n.d.). Ngati Whare at the end of the wars. Retrieved March 2, 2010

from 
http://www.ngatiwhare.org.nz/panui/Ngati_Whare_History_Articl e_2_-_Te_Kooti.pdf.

Anon. Protesters to talk to Maori MPs about Bay of Plenty road block. Waikato Times, 11 August 2009.

Aranga, M. (2002). Aspects of mätauranga Māori: A hermeneutic exploration of whakapapa and knowledge. Unpublished master's thesis, Te Whare Wānanga o Awanuiārangi, Whakatāne, New Zealand.

Arapere, B. (2002). A history of the Waiohau blocks: A report commissioned by the Waitangi Tribunal. New Zealand: Waitangi Tribunal. (WAI 894 \#A26).

Archie, C. (2005). Skin to skin: Intimate, true stories of Maori-Pakeha relationships. Auckland: Penguin Books.

Audi, R. (1999). The Cambridge dictionary of philosophy (2nd edition). Cambridge, UK: Cambridge University Press.

Awatere, D. (1984). Maori sovereignty. Auckland: Broadsheet.

Ballara, A. (1996). Introduction. In Te Kingitanga: The people of the Maori king movement (pp. 1-32).Fourteen biographies from the Dictionary of New Zealand Biography. Auckland: Auckland University Press.

Ballara, A. (1998). Iwi: The dynamics of Māori tribal organisation from c. 1769 to c. 1945 . Wellington: Victoria University Press.

Bamshad, M. J. \& Olson, S. E. (2003, December). Does race exist? Scientific American, 289, 6.

Banton, M. (1998). Racial theories (2 ${ }^{\text {nd }}$ edition). Cambridge: Cambridge University Press.

Barker, C. (2008). Cultural studies: Theory and practice (3 ${ }^{\text {rd }}$ edition). London: Sage Publications Ltd.

Barlow, C. (1991). Tikanga whakaaro: Key concepts in Māori culture. South Melbourne: Oxford University Press.

Belgrave, M. (2005). Historical frictions: Maori claims and reinvented histories. Auckland: Auckland University Press.

Belgrave, M., Kawharu, M. \& Williams, D. (2005). Waitangi revisited: Perspectives on the Treaty of Waitangi. Melbourne: Oxford University Press.

Belich, J. (1986). The New Zealand wars. Auckland: Penguin.

Belich, J. (1988). The New Zealand wars and the Victorian interpretation of racial conflict. Auckland: Penguin Books.

Belich, J. (1996). Making peoples: A history of the New Zealanders from Polynesian settlement to the end of the nineteenth century. Auckland: Penguin Books.

Belich, J. (2001). Paradise forged: A history of the New Zealanders from the 1880s to the year 2000. Auckland: Penguin Books.

Belich, J. (2001). Myth, race, and identity in New Zealand. In J. Binney (Ed.). The shaping of history: Essays from the New Zealand Journal of History (pp. 356-66). Wellington: Bridget Williams Books.

Belich, J. (2009). Riders in the whirlwind: Tribal peoples and European settlement booms, 1790s-1900s. In R. Boast \& R. S. 
Hill (Eds.). Raupatu: The confiscation of Maori land (pp. 33-27). Wellington: Victoria University Press.

Bell, L. (1980). The Maori in European art: A survey of the representation of Maori by European artists from the time of Captain Cook to the present day. A. H. \& A. W. Reed: Auckland.

Bell, L. (1992). Colonial constructs: European images of Maori 18401914. Auckland University Press: Auckland.

Bentley, T. (1999). Pakeha Maori: The extraordinary story of the Europeans who lived as Maori in early New Zealand. Auckland: Penguin Books.

Bentley, T. (2004). Captured by Maori: White female captives, sex and racism on the nineteenth-century New Zealand frontier. Auckland: Penguin Books.

Bentley, T. (2007). Images of Pakeha-Maori: A study of the representation of Pakeha-Maori by historians of New Zealand from Arthur Thomson (1859) to James Belich (1996). Unpublished doctoral thesis, University of Waikato, Hamilton, New Zealand.

Best, E. (1923). The Maori school of learning: Its objects, methods, and ceremonial. Wellington: Dominion Museum, Government Printer.

Best, E. (1925). Tuhoe: Children of the mist. Auckland: Reed Publishing (NZ) Limited.

Bhabha, H. K. (1983). The other question...Homi K. Bhabha reconsiders the stereotype and colonial discourse. Screen, 24(6), 18-36.

Bhabha, H. K. (1994). The location of culture. London: Routledge.

Bhattacharyya, G., Gabriel, J. \& Small, S. (2002). Race and power: Global racism in the twenty-first century. London: Routledge.

Bhui, H. S. (Ed.). (2009). Race and criminal justice. London: Sage.

Binney, J. (1997). Redemption songs: A life of Te Kooti Arikirangi Te Turuki. Auckland, New Zealand: University Press and Bridget Williams Books.

Binney, J. (2001a). Te Umutaoroa: The earth oven of long cooking. In A. Sharp \& P. McHugh (Eds.), Histories, power and loss: Uses of the past - a New Zealand commentary (pp. 146-64). Wellington, New Zealand: Bridget Williams Books Limited.

Binney, J. (Ed.). (2001b). The shaping of history: Essays from the New Zealand Journal of History. Wellington: Bridget Williams Books.

Binney, J. (2002). Encircled lands, part one: A history of the Urewera from European contact until 1878. An overview report on the Urewera (Wai 894 \# A15). Report to the Waitangi Tribunal, Wellington, New Zealand.

Binney, J. (2003). Statement of Judith Binney in response to questions of clarification. Wai 894. Submission to the Waitangi Tribunal, Wellington, New Zealand.

Binney, J. (2007a). When the white kawau flies. In J. Lutz (Ed.), Myth and memory: Stories of Indigenous-European contact (140-159). Vancouver: UBC Press.

Binney, J. (2007b). Te Kooti Arikirangi Te Turuki ? - 1893. In Dictionary of New Zealand Biography, updated 22 June 2007. 
Retrieved August 25, 2009 from http:/ / www.dnzb.govt.nz/DNZB/alt_essayBody.asp?essayID=1T4 5.

Binney, J. (2009a). Encircled lands: Te Urewera, 1820-1921. Wellington: Bridget Williams Books.

Binney, J. (2009b). Te upokokohua: the curse of confiscation on Te Urewera. In R. Boast \& R. S. Hill (Eds.). Raupatu: The confiscation of Maori land (pp. 222-32). Wellington: Victoria University Press.

Binney, J., Bassett, J. \& Olssen, E. (1990). The people and the land: An illustrated history of New Zealand 1820-1920. Wellington: Allen \& Unwin New Zealand Limited \& Port Nicholson Press.

Binney, J., Chaplain, G., \& Wallace, C. (1979). Mihaia: The prophet Rua Kenana and his community at Maungapohatu. Auckland: Auckland University Press.

Bird, H. T. (1980). Kuranui o Ngati Manawa. Rotorua: H. T. Bird.

Bishop, R. (1996a). Addressing issues of self determination and legitimation in Kaupapa Māori research. In B. Webber (Ed.), He paepae kōrero: Research perspectives in Māori education. Wellington: NZCER.

Bishop, R. (1996b). Collaborative research stories: Whakawhanaungatanga. Palmerston North: Dunmore Press.

Bishop, R. (1999). Kaupapa Maori research: An Indigenous approach to creating knowledge. In Maori and psychology: Research and practice - the proceedings of a symposium sponsored by the Maori and psychology research unit, 26 August 1999 (pp.1-6). Hamilton, New Zealand: Maori \& Psychology Research Unit.

Bishop, R. (2005). Freeing ourselves from neo-colonial domination in research: A Kaupapa Māori approach to creating knowledge. In N. K. Denzin \& Y. S. Lincoln (Eds.), The sage handbook of qualitative research (3 $3^{\text {rd }}$ edition., pp. 109-138). Thousand Oaks, California: Sage.

Bishop, R., \& Berryman, M. (2006). Culture speaks: Cultural relationships and classroom learning. Wellington: Huia.

Bishop, R., \& Glynn, T. (1999). Culture counts: Changing power relations in education. Palmerston North: Dunmore Press.

Boast, R. P. (2002). The Crown and Te Urewera in the 20th century - a study of government policy. Report to the Waitangi Tribunal, Wellington, New Zealand.

Boast, R. (2008). Buying the land, selling the land: Governments and Maori land in the North Island 1865-1921. Wellington: Victoria University Press.

Boast, R. (2009). 'An expensive mistake': Law, courts, and confiscation on the New Zealand colonial frontier. In R. Boast \& R. S. Hill (Eds.). Raupatu: The confiscation of Maori land (pp. 145-67). Wellington: Victoria University Press.

Boast, R. \& Hill, R. S. (Eds). (2009). Raupatu: The confiscation of Maori land. Wellington: Victoria University Press. 
Boast, R. \& Hill, R. S. (2009). Overview: confiscation in New Zealand. In R. Boast \& R. S. Hill (Eds.). Raupatu: The confiscation of Maori land (pp. 3-12). Wellington: Victoria University Press.

Bolaffi, G., Bracalenti, R., Braham, P., \& Gindro, S. (2003). Dictionary of race, ethnicity and culture. London: Sage Publications.

Bolt, C. (1971). Victorian attitudes to race. Great Britain: Routledge \& Keegan Paul Limited.

Boyes, S (2006). Mai i ngā ao e rua-from two worlds: an investigation into the attitudes towards half castes in New Zealand. Unpublished honours dissertation, University of Otago, Dunedin.

Bright, N. (1997). Tuhoe and the government: A question of autonomy. Unpublished masters thesis, Massey University, Palmerston North.

Brookfield, F. M. (2004). Brief of evidence of Professor Frederic Morris Brookfield dated the 20 th day of February 2004. Wai 894/ Wai 726. Submission to the Waitangi Tribunal, Wellington, New Zealand.

Brookfield, F. M. (2005). Waitangi and the legal systems of Aotearoa New Zealand: conflict and change. In M. Belgrave, M. Kawharu \& D. Williams (Eds.). Waitangi revisited: Perspectives on the Treaty of Waitangi (pp. 349-365). Melbourne: Oxford University Press.

Brooking, T. (1985). "Tam McCanny and Kitty Clydeside": the Scots in New Zealand. In R. Cage (Ed.). The Scots abroad: Labour, capital, enterprise 1750-1914 (pp. 156-90). London: Croom Helm.

Brooking, T. (1996). Lands for the peoples? The highland clearances and the colonisation of New Zealand: A biography of John McKenzie. Dunedin: University of Otago Press.

Brown, R. (1965). Social Psychology. London: Macmillan.

Buck, P. H. (1924). The passing of the Maori. Wellington: Government Printer.

Burns, E. B. (1977). Latin America: a concise interpretive history. New Jersey: Prentice Hall.

Bush, L. E. (1984). Mormonism's Negro doctrine: an historical review. In L. E. Bush \& A. L. Mauss (Eds.), Neither White nor Black: Mormon scholars confront the race issue in a universal church (no page number). Midvale, Utah: Signature Books. Retrieved September 3, 2009 from

http://www.signaturebookslibrary.org/neither/neither3.htm\#Cha pter3.

Bush, L. E. \& Mauss, A. L. (Eds.). (1984). Neither White nor Black: Mormon scholars confront the race issue in a universal church. Midvale, Utah: Signature Books. Retrieved September 3, 2009 from http://www.signaturebookslibrary.org/neither/neithertitle.htm.

Bynum, W. F. (1975). The great chain of being after forty years: An appraisal. History of Science 13, 1-28. Retrieved August 31, 2009 from http://adsabs.harvard.edu/full/1975HisSc..13....1B.

Byrnes, G. (2001). Boundary markers: Land surveying and the colonisation of New Zealand. Wellington: Bridget Williams Books. 
Byrnes, G. (2004). The Waitangi Tribunal and New Zealand history. Melbourne: Oxford University Press.

Byrnes, G. (2009). The new Oxford history of New Zealand. South Melbourne, Victoria: Oxford University Press.

Carr, E. H. (1964). What is history? London: Pelican.

Carter, J. (2000). None of us is what our tūpuna were: When 'growing up Pākehā' is 'growing up Māori'. In W. Ihimaera (Ed.), Growing up Mãori. Auckland: Publishing Press Limited.

Cheater, A. \& Hopa, N. (1997). Representing identity. In A. James, J. Hockey \& A. Dawson (Eds.), After writing culture: Epistemology and praxis in contemporary anthropology (pp. 208-23). Oxon: Routledge.

Chouki, E. (2002). Race, slavery and Islam in Maghribi Mediterranean thought: The question of the Haratin in Morocco. The Journal of North African Studies, 7(3), 39-42.

Cleaver, P. (2002). Urewera roading: A report for the Crown Forest Rental Trust. Wellington: Crown Forest Rental Trust.

Colman, A. M. (2006). Oxford dictionary of psychology. New York: Oxford University Press.

Cowan, J. (1922). The New Zealand wars: A history of the Maori campaigns and the pioneering period (2 vols). Wellington: Government Printer.

Cram, F., Pihama, L. \& Barbara, G. P. (2000). Māori and genetic engineering. Research report, International Research Institute for Maori and Indigenous Education, University of Auckland, Auckland.

Cresswell, J. C. M. (1977). Maori meeting houses of the North Island. Auckland: PCS Publications.

Crosby, R. (2004). Gilbert Mair: Te Kooti's nemesis. Auckland: Reed Publishing.

Dalal, F. (2002). Race, colour and the processes of racialization. New York: Routledge.

Dalton, B. J. (1967). War and politics in New Zealand, 1855-1870. Sydney: Sydney University Press.

Daly, J. P. (2004). When slavery was called freedom: Evangelicalism, proslavery, and the causes of the Civil War. Kentucky: University Press of Kentucky.

Daniels, D. (2008). Racism and discrimination after emancipation [Video]. Retrieved September 7, 2009 from http://www.youtube.com/watch?v=EOwnPN9kBiY\&feature=chan nel.

Davis, H. (2004). Understanding Stuart Hall. London: Sage Publications.

Delany, M. R. (1879). Comparative elements of civilization. In J. O. Ifekwunigwe (Ed.), 'Mixed race' studies: A reader. New York: Routledge.

Deloria, V. (1999). For this Land: Writings on Religion in America. New York: Routledge. 
Deloria, V., Jr. (2002). Evolution, creationism, and other modern myths: A critical inquiry. Golden, Colorado: Fulcrum.

Derrida, J. (1972). Positions. Chicago: University of Chicago Press.

Dikötter, F. (1992). The discourse of race in modern China. Stanford: Stanford University Press.

Doherty, W. (1995). Traditional history relating to Matahina $C \& C 1 \&$ Te Patuheuheu and Ngati Haka. Te Runanganui o Te Ika Whenua - WAI 212.

Donald, J. \& Rattansi, A. (Eds.). (1992). 'Race', culture and difference. London: Sage Publications.

Durie, M. (1998). Te mana, te kāwanatanga: The politics of Mãori selfdetermination. South Melbourne, Australia: Oxford University Press.

Elsmore, B. (1999). Mana from heaven: A century of Maori prophets in New Zealand. Auckland: Reed Publishing (NZ) Limited.

Elsmore, B. (2000). Like them that dream: The Maori and the old testament. Auckland: Reed Publishing (NZ) Limited.

Erikson, C. (1972). Invisible immigrants. The adaption of English and Scottish immigrants in nineteenth century America. London: Weidenfeld \& Nicolson.

Evison, H. C. (1997). The long dispute: Maori land rights and European colonisation in southern New Zealand. Christchurch: Canterbury University Press.

Fagan, B. M. (1983). People of the earth: An introduction to world prehistory. Boston: Little Brown.

Fairburn, M. (1979). Social mobility and opportunity in nineteenth century New Zealand. New Zealand Journal of History, 13(1), 4360.

Fairburn, M. (1989). The ideal society and its enemies: The foundations of modern New Zealand society 1850-1900. Auckland: Auckland University Press.

Fanon, F. (1963). The wretched of the earth (C. Farrington, Trans.). New York: Grove Press.

Fanon, F. (1986). Black skin, white masks (C. L. Markmann, Trans.). London: Pluto Press.

Farr, A. (2009). The spectre of race: bell hooks, deconstruction, and revolutionary blackness. In M. Davidson \& G. Yancy (Eds.), Critical perspectives on bell hooks (pp. 156-64). New York: Routledge.

Foucault, M. (1978). The history of sexuality. Volume one: An introduction (R. Hurley, Trans.). London: Allen Lane.

Foucault, M. (1980). Power/knowledge. New York: Penguin.

Foucault. M. (1990). The history of sexuality. volume one: an introduction (R. Hurley, Trans.). New York: Vintage Books.

Foucault, M. (1998). The will to knowledge: the history of sexuality, volume one (R. Hurley, Trans.). London: Penguin.

Foucault, M. (2003). Society must be defended. London: Penguin Books.

Freeman, D. (2010). The Pacific. Oxon: Routledge. 
Fredrickson, G. M. (2002). Racism: A short history. Princeton University Press: New Jersey.

Friedberg, L. (2000). Dare to Compare: Americanizing the Holocaust. The American Indian Quarterly, 24(3), 353-80.

Gates, H. L. (1986). "Race" as the trope of the world. In H. L. Gates (Ed.), 'Race', writing and difference (pp. 4-13). Chicago: University of Chicago Press.

Gidley, M. (Ed.). (1992). Representing others: White views of Indigenous peoples. Exeter: University of Exeter Press.

Gilling, B. (2009). Raupatu: Punitive confiscation of Maori land in the 1860s. In R. Boast \& R. S. Hill (Eds.). Raupatu: The confiscation of Maori land (pp. 13-30). Wellington: Victoria University Press.

Glasse, C. (2008). The new encyclopedia of Islam. Walnut Creek, California: Rowman \& Littlefield Publishers.

Gobineau, J.A. (1853). Recapitulation: The respective characteristics of the three great races; The superiority of the white type, and, within this type, of the Aryan family. In J. O. Ifekwunigwe (Ed.), 'Mixed race' studies: A reader. New York: Routledge.

Goldenberg, D. M. (2003). The curse of Ham: Race and slavery in early Judaism, Christianity, and Islam. Princeton: Princeton University Press.

Gordon, L. R., Sharpley-Whiting, T. D. \& White, R. T. (Eds.). (1996). Fanon: A critical reader. Oxford: Blackwell Publishers.

Gould, S. J. (1981). The mismeasure of man (1 ${ }^{\text {st }}$ edition). New York: W. W. Norton \& Company Incorporated

Gould, S. J. (1995). Ghosts of bell curves past. Natural History, 104, 12-19.

Gould, S. J. (1996). The mismeasure of man (2nd edition). New York: W. W. Norton \& Company Incorporated.

Graham, B. T. (1990). Mo nga hara o nga tribe o Waikato: An investigation into the impact of the Waikato confiscations on the Waikato and Hauraki tribes in the Wairoa block 1860-70. Unpublished master's dissertation, University of Waikato, Hamilton.

Graham B. T. (1995). Riding someone else's waka: academic theory and tribal identity. In P. Suvendrini (Ed.), Asian and Pacific inscriptions: identities/ethnicities/nationalities (pp. 46-63). A special issue of Meridian. Melbourne: La Trobe University.

Graham, B. T. (2003). The discourse of the "possessive individual" and the shaping of Indigenous identity in Aotearoa/New Zealand. A paper presented to the conference of the British Philosophy Association, 11-13 April 2003. Oxford, England.

Grover, M. L. (1984). Religious accommodation in the land of racial democracy: Mormon priesthood and black Brazilians. Dialogue, 17(3), 23-34. Retrieved October 29, 2009 from http://www.mormonismi.net/pdf/race_in_brazil.pdf.

Gunn, D. M. (1998). Colonialism and the vagaries of scripture: Te Kooti in Canaan. A Story of Bible and dispossession in Aotearoa/New Zealand. In T. Linafelt \& T. K. Beal (Eds.). God in 
the fray: A tribute to Walter Brueggemann (pp. 127-142). Minneapolis: Ausburg Fortress Press. Retrieved September 9, 2009 from http://www.gunnzone.org/DMG_TCU/TeKooti.html.

Hackshaw, F. (1989). Nineteenth century notions of aboriginal title and their influence on the interpretation of the Treaty of Waitangi. In I. H. Kawharu (Ed.). Waitangi: Maori and Pakeha perspectives of the Treaty of Waitangi (pp. 92-120). Auckland: Oxford University Press.

Hall, S. (1992a). The west and the rest: Discourse and power. In S. Hall and B. Gielben (Eds.), Formations of modernity (pp. 276-320). Cambridge: Polity Press and Open University.

Hall, S. (1992b). New ethnicities. In J. Donald \& A. Rattansi (Eds.). 'Race', culture and difference (pp. 252-259). London: Sage Publications.

Hall, S. (1994). Cultural identity and Diaspora. In P. Williams and L. Chrisman (Eds.), Colonial discourse and post-colonial theory: A reader (pp. 392-403). New York: Columbia University Press.

Hall, S. (1997). The spectacle of the 'other'. In S. Hall (Ed.), Representation: Cultural representations and signifying practices (pp. 225-92). London: Sage.

Haller, J. S. (1995). Outcasts from evolution: Scientific attitudes of racial inferiority, 1859-1900. Illinois: Southern Illinois University Press.

Harvey, G. (2005). Animism: Respecting the living world. Kent Town, South Australia: Wakefield Press.

Haynes, S. R. (2002). Noah's curse: The biblical justification for American slavery. New York: Oxford University Press.

Hickford, M. (2009). Strands from the afterlife of confiscation: Property rights, constitutional histories and the political incorporation of Maori, 1920s. In R. Boast \& R. S. Hill (Eds.). Raupatu: The confiscation of Maori land (pp. 169-203). Wellington: Victoria University Press.

Hoeveler, D. L., \& Cass, J. (2006). Interrogating Orientalism: Contextual approaches and pedagogical practices. Columbus, $\mathrm{OH}$ : Ohio State University Press.

Hoffman, P (1994). The Science of Race. Discover, 15(2), 4.

Hokowhitu, B. (2001). Te mana Māori - te tātari i ngā kōrero parau. Unpublished doctoral thesis, University of Otago, Dunedin, New Zealand.

Hokowhitu, B. (2003). Race tactics: The racialised athletic body. Junctures 1, 21-34. Retrieved August 31, 2009 from http://www.junctures.org/articles/01body021.pdf.

Hokowhitu, B. (2004). Tackling Māori masculinity: A colonial genealogy of savagery and sport. The Contemporary Pacific, 16(2), 259-284. Retrieved August 31, 2009 from https:/ / faculty.washington.edu/pembina/all_articles/Hokowhitu 2004.pdf.

Hokowhitu, B. (2009). Indigenous existentialism and the body. Cultural Studies Review (critical Indigenous theory), 15(2), 101-18. 
Holy Bible (1979). King James version. Cambridge: University Press.

Howard-Vagner, D. (2007). Colonialism and the science of race difference. In TASA and SANZ Joint Conference Refereed Conference Proceedings - Public Sociologies: Lessons and TransTasman Comparisons, 4-7 December 2007. Auckland, New Zealand. Retrieved September 4, 2009 from http://www.arts.usyd.edu.au/departs/ssp/docs/TASA-SAANZScience\%20of\%20Race\%20Difference.pdf.

Hudson, N. (1996). From Nation to Race: The Origin of racial classification in eighteenth century thought. Eighteenth Century Studies, 29 (3), 247-264.

Isaac, B. (2004). The invention of racism in classical antiquity. Princeton: Princeton University Press.

Jackson, M. (2000). Where does sovereignty lie? In C. James (Ed.). Building the constitution (196-200). Wellington: Institute of Policy Studies, Victoria University of Wellington.

Jahoda, G. (1999). Images of savages: Ancient roots of modern prejudice in Western culture. New York: Routledge.

Jaimes, M. A. (1995). Some kind of Indian: On race, eugenics and mixed blood. In N. Zack (Ed.), American mixed race (pp. 133-153). London: Rowman \& Littlefield.

James, A., Hockey, J. \& Dawson, A. (Eds). (1997). After writing culture: Epistemology and praxis in contemporary anthropology. Oxon: Routledge.

Johnson, R. (1979). Culture and the historians. In J. Clarke, C. Critcher \& R. Johnson (Eds.), Working class culture: Studies in history and theory. London: Hutchinson.

Johnston, P. M. (1998). He ao rereke: Education policy and Maori under-achievement: mechanisms of power and difference. Unpublished doctoral thesis, University of Auckland, Auckland.

Johnston, P. M (1999). Patrons of Maori culture: Power, theory and ideology in the Maori renaissance (book review). New Zealand Sociology, 14(1).

Johnston, P. M. (2001). When Indigenous knowledge destabilizes the borders: Research in Aotearoa/New Zealand. Paper presented at the Indigenous Knowledge Conference, University of Saskatchewan, Saskatoon, Canada, 28-30 May 2001.

Johnston, P. M. (2010). Diversity, discrimination or difference: case study Aotearoa/New Zealand. Indian Institute of Dalit Studies, Working Paper Series, 4(1), 1-32.

Jones, L. (1998). Pakeha representations of Maori in the popular print media 1935-1965. Unpublished master's thesis, University of Auckland, Auckland, New Zealand.

Ka'ai, T. (1990). Te hiringa taketake: Mai te kohanga reo ki te kura: Maori pedagogy: Te kohanga reo and the transition to school. Unpublished master's thesis, University of Auckland, Auckland, New Zealand.

Ka'ai, T. (1995). Te tātari $i$ te kaupapa. Unpublished doctoral thesis, University of Waikato, Hamilton, New Zealand. 
Ka'ai, T. M., Moorfield, J. C., Reilly, M. P. J. \& Mosley, S. (Eds.). (2004). Ki te whaiao: An introduction to Māori culture and society. Auckland: Pearson Education New Zealand.

Karetu, T. (1992). Language and protocol of the marae. In M. King (Ed.), Te ao hurihuri: Aspects of Maoritanga (pp. 28-41). Auckland: Reed Publishing.

Karetu, T. (1993). Haka! The dance of a noble people. Auckland: Reed Books.

Kawharu, I. H. (1977). Maori land tenure: Studies of a changing institution. Oxford: Clarendon Press.

Kawharu, I. H. (Ed.). (1989). Waitangi: Maori and Pakeha perspectives of the Treaty of Waitangi. Auckland: Oxford University Press.

Kennedy, V. (2000). Edward Said: A critical introduction. Malden USA: Blackwell Publishers Inc.

Kimbal, S. W. (1978). Declaration Two, from the Doctrine and Covenants. Salt Lake City: The Church of Jesus Christ of LatterDay Saints.

King, M. (Ed.). (1992). Te ao hurihuri: Aspects of Maoritanga. Auckland: Reed Publishing.

King, M. (1996). Maori: A photographic and social history. Auckland: Reed Publishing.

King, M. (1997). Nga iwi o te motu: 1000 years of Maori history. Auckland: Reed Publishing.

King, M. (2004). The Penguin history of New Zealand illustrated. Auckland: Penguin Books.

Lewis, B. (1990). Race and slavery in the Middle East: An historical enquiry. Oxford: Oxford University Press.

Lewis, B. (1991). The political language of Islam. Chicago: University of Chicago Press.

Lewontin, R. (2008). The concept of race: The confusion of social and biological reality [Video]. Retrieved September 7, 2009 from http:/ / www.youtube.com/watch?v=JvG1ylKhzoo\&feature=related.

Lidchi, H., (1997). The poetics and the politics of exhibiting other cultures. In S. Hall (Ed.), Representation: Cultural representations and signifying practices (pp. 151-208). London: Sage.

Little, E. E. (1973). Memories of Waiohau. In Te Ao Hou: The new world, 73, 27-34. July.

Lovejoy, A. O. (1964). The great chain of being: A study of the history of an idea. Cambridge, Massachusetts: Harvard University Press.

Lutz, J. (Ed.). (2007). Myth and memory: Stories of IndigenousEuropean contact. Vancouver: UBC Press.

Macey, D. (2000). The penguin dictionary of critical theory. London: Penguin Books Limited.

MacDonald, R. (1990). The Maori of Aotearoa New Zealand. London: Minority Rights Group.

MacFarlane, A.H. (2004). Kia Hiwa Ra! Listen to culture - Māori students' plea to educators. Wellington: Print Link.

Mahuta, R. T. (1990). Raupatu: the search for justice. In New Zealand Planning Council, Puna Wairere: Essays by Maori. 
Marks, J. (2008). Great chain of being. In J. H. Moore (Ed.). The encyclopedia of race and racism (pp. 68-73). Detroit: Macmillan Reference.

Mauss, A. L. (1984). The fading of the pharaohs' curse: The decline and fall of the priesthood ban against blacks in the Mormon Church. In L. E. Bush \& A. L. Mauss (Eds.), Neither White nor Black: Mormon scholars confront the race issue in a universal church (no page number). Midvale, Utah: Signature Books. Retrieved September 3, from http:// www.signaturebookslibrary.org/neither/neither5.htm.

Mautner, T. (2000). Dictionary of philosophy. London: Penguin Books.

Mayhew, H. (1968). London labour and the London poor, Volume One. New York: Dover Publications.

McCaskell, T. (n. d.). A history of race/ism [Document]. Retrieved August 31, 2009 available from http:/ / scholar.google.co.nz/scholar?start=110\&q=great+chain+of +being+and+race\&hl=en.

McLean, G. (1992). Local history: A short guide to researching, writing and publishing a local history. Bridget Williams Books \& Historical Branch, Department of Internal Affairs.

McLean, L. (1996). Oxford concise dictionary of politics. Oxford: Oxford University Press.

McClintock, A., (1995). Imperial leather: Race, gender and sexuality in the colonial contest. New York: Routledge.

McGrath, N. (2007). Dialoguing in the desert for sustainable development: Ambivalence, hybridity and representations of Indigenous people. Unpublished doctoral thesis, Murdoch University, Perth, Australia.

McNaughton, T. O. P. (2004). Re-viewing identities: Constructions of Māori in New Zealand children's picture books. Unpublished master's thesis, University of Auckland, Auckland.

Mead, S. M. (1997). Landmarks, bridges and visions: Aspects of Maori culture. Wellington: Victoria University Press.

Mead, H. M. (2003). Tikanga Māori: Living by Māori values. Wellington: Huia Publishers.

Mead, L.T. (1997). Nga aho o te kakahu matauranga: Multiple layers of struggle by Maori in education. Unpublished doctoral thesis, The University of Auckland, Auckland.

Melamed, A. (2003). The image of the black in Jewish culture: A history of the other. London: Routledge Curzon.

Memmi, A. (1990). The colonizer and the colonized (H. Greenfeld, Trans.). London: Earthscan Publications.

Mercer, G. Public road blocked to stop Treaty deal. Whakatane Beacon, 11 August 2009.

Mercer, G. Protester died while protecting his land. Whakatane Beacon, 19 August 2009.

Mika, C. (2005). When the "Gaze" meets the "gaze": Medical science and its normalisation of the Maori body. Unpublished master's 
thesis, Te Whare Wānanga o Awanuiārangi, Whakatane, New Zealand.

Mika, C. (2007). The utterance, the body and the law: Seeking an approach to concretizing the sacredness of Maori language. Sites: A Journal for South Pacific Cultural Studies, 4(2) 2007, 181-205.

Mikaere, A. (2005). The Treaty of Waitangi and recognition of tikanga Māori. In M. Belgrave, M. Kawharu \& D. Williams (Eds.). Waitangi revisited: Perspectives on the Treaty of Waitangi (pp. 330-348). Melbourne: Oxford University Press.

Miles, A. (1999). Te Urewera. Working paper, first release, rangahaua whanui series. Wellington: Waitangi Tribunal.

Miles, R. (1989). Racism. London: Routledge.

Miles, R. (2003). Racism (2nd edition). London: Routledge.

Miller, H. (1966). Race conflict in New Zealand 1814-1865. Auckland: Blackwood \& Janet Paul.

Miller, J. (1958). Early Victorian New Zealand: A study of racial tension and social attitudes 1839-1852. Oxford University Press: London.

Mingay, G. E. (Ed.). (1981). The Victorian countryside. London: Routledge \& Keegan Paul.

Misur, G. Z. (2003). From prophet cult to established church: The case of the Ringatu movement. In I. H. Kawharu, Conflict and compromise: Essays on the Maori since colonisation (pp. 97-115). Auckland: Reed.

Mizutani, S. (2002). Rethinking inclusion and exclusion: The question of mixed-race presence in late colonial India. University of Sussex Journal of Contemporary History, 5, 1-22. Retrieved on September 4, 2009 from http://www.sussex.ac.uk/history/documents/satoshimizutani.pd f.

Molenda, M. (2008) Historical Foundations. In M. Spector (Ed.), Handbook of research on educational communications and technology (pp. 3-20). New York: Taylor \& Francis e-Library.

Montagu, A. (Ed.). (1999). Race and IQ: Expanded edition. Oxford University Press: New York.

Montagu, M. F. A. (Ed.). (1962). Culture and the evolution of man. Oxford University Press: New York.

Moon, P. \& Biggs, P. (2004). The Treaty and its times: The illustrated history. Auckland: Resource Books.

Moore, G. C. (1981a). The landed aristocracy. In G. E. Mingay (Ed.). The Victorian countryside (volume two, pp. 367-82). London: Routledge \& Keegan Paul.

Moore, G. C. (1981b). The gentry. In G. E. Mingay (Ed.). The Victorian countryside (volume two, pp. 383-98). London: Routledge \& Keegan Paul.

Moreira-Slepoy, G. (2002). The Essentialist Representation of the Colonial Subject in Colonial Discourse. www.post-scriptum.org, 1, para. 1-28. Retrieved September 4, 2009 from http://www.postscriptum.org/flash/docs2/art_2002_01_004.pdf. 
Moreton-Robinson, A. (2009). Imagining the good Indigenous citizen: Race war and the pathology of patriarchal white sovereignty. Critical Indigenous Theory: Cultural Studies Review, 15(2), 61-79.

Mulholland, M. (Ed.). (2006). State of the Māori nation: Twenty-firstcentury issues in Aotearoa. Auckland: Reed Publishers.

Mutu, T. (2000). Ko te mana kei a tātou anō - he iwi hoki tātou. Unpublished master's thesis, University of Waikato, Hamilton, New Zealand.

Nealon, J. \& Giroux, S. S. (2003). The theory toolbox: Critical concepts for the humanities, arts, and social sciences. Lanham: Rowman \& Littlefield.

Neich, R. (1993). Painted histories: Early Maori figurative painting. Auckland: Auckland University Press.

Nicholson, J. (2006). White chief: The colourful life and times of Judge F. E. Maning of the Hokianga. Auckland: Penguin.

Nicole, R. (2001). The word, the pen, and the pistol: Literature and power in Tahiti. Albany: State University of New York Press.

Nikora, T. (2004a). Tuhoe and the Rangitaiki. Report for the Waitangi Tribunal.

Nikora, T. R. (2004b). Statement of evidence of Tamaroa Raymond Nikora for third hearing week. 18 March 2004. Submission to the Waitangi Tribunal.

Nottingham, S. (2002). Genescapes: The ecology of genetic engineering. London: Zed Books.

O'Malley, V. (1998). Agents of autonomy: Maori committees in the nineteenth century. Wellington: Huia Publishers.

O'Malley, V. (2009). 'A mild sort of confiscation'? War and raupatu on the east coast. In R. Boast \& R. S. Hill (Eds.). Raupatu: The confiscation of Maori land (pp. 207-21). Wellington: Victoria University Press.

Openshaw, R. \& Rata, E. (2008). Flax rope or iron fetter? How cultural essentialism threatens intellectual freedom in the New Zealand tertiary education sector. The New Zealand Journal of Tertiary Education Policy, 3(1), December 2008. Retrieved August 27, 2009 from http://www.teu.ac.nz/wpcontent/uploads/2008/12/oppenshawrata.pdf.

Ogot, B. A. (1974). Zamani: A survey of east African history. Nairobi: East African Publishing House.

Orange, C. (1987). The Treaty of Waitangi. Wellington: Bridget Williams Books.

Pajaczkowska, C. \& Young, L. (1992). Racism, representation, psychoanalysis. In J. Donald \& A. Rattansi (Eds.). 'Race', culture and difference (pp. 198-219). London: Sage Publications.

Paul, G. M. (1995). Te Houhi and Waiohau 1B. Te Runanganui o Te Ika Whenua - WAI 212.

Pearson, D. (1990). A dream deferred: The origins of ethnic conflict in New Zealand. Allen \& Unwin: New Zealand.

Pearson, D. (2001). The politics of ethnicity in settler societies: States of unease. New York: Palgrave. 
Perdew, P. R. (2001). Developmental education and Alfred Binet: The original purpose of standardized testing. In J. L. Higbee, D. B. Lundell, I. M. Duranczyk \& D. Banerjee-Stevens (Eds.). 2001: A developmental odyssey (pp. 71-85). Retrieved September 1, 2009 from

http://www.nade.net/documents/Mono\%2001/monograph01.pdf \#page $=77$.

Pere, R. R. (1994). Ako: Concepts and learning in the Maori tradition. Wellington: Te Kohanga Reo National Trust Board.

Petrie, H. (1998). The 'lazy Maori': Pakeha representations of a Maori work ethic 1890-1940. Unpublished master's thesis, University of Auckland, Auckland.

Petrie, H. (2006). Chiefs of industry: Maori tribal enterprise in early colonial New Zealand. Auckland: Auckland University Press.

Pihama, L. (1993). Tungia te ururua, kia tupu whakaritorito te tupu o te harakeke: A critical analysis of parents as first teachers. Unpublished master's thesis, University of Auckland, Auckland.

Pihama, L. (1994). Redrawing the maps: The plural society and its futures, in Te Pua, Vol. 3 No. 2, 37-41.

Pihama, L. (2001). Tìhei mauri ora honouring our voices: Mana wahine as a kaupapa Māori theoretical framework. Unpublished doctoral thesis, The University of Auckland, Auckland, New Zealand.

Polack, J. S. (1840). Manners and customs of the New Zealanders: With notes corroborative of their habits, usages, etc., and remarks to intending emigrants, with numerous cuts drawn on wood, volume one. London: James Madden.

Polack, J. S. (1976 [1840]). Manners and customs of the New Zealanders, volume one. Christchurch: Capper Press.

Ponzanesi, S. (2001). Beyond the black venus: Colonial sexual politics and contemporary visual practices. In J. Andall \& D. Duncan (Eds.), Italian Colonialism. Legacies and Memories (pp. 165-189). Oxford: Peter Lang. Retrieved September 4, 2009 from http://www.uu.nl/wiredup/sandra/Black\%20Venus\%2010Chapt er8B1651.pdf

Popper, K. R. (1959). Prediction and prophecy in the social sciences. In P. Gardiner (Ed.), Theories of history (pp. 276-85). New York: The Free Press.

Porima, M. (1994). Matahina $C \& C 1 \&$ Te Patuheuheu \& Ngati Haka: Preliminary report. Murupara: Te Runanganui o Te Ika Whenua.

Pouwhare, T. (1958). Waiohau. In Te Ao Hou: The new world, 25, 19. December.

Pouwhare, T. (1996). He korero mo Tama-ki-Hikurangi: Ngati Haka a hapu of Tuhoe. Unpublished research report, University of Waikato, Hamilton, New Zealand.

Pouwhare, R. M. I. (2004). Brief of evidence of Robert Marunui Iki Pouwhare dated the 14th day of March 2004. Wai 894/Wai 726. Submission to the Waitangi Tribunal, Wellington, New Zealand.

Pouwhare, R. M. I. (2007). Pouwhare, Te Iki-o-te-rangi 1880-1883? 1963. 
Dictionary of New Zealand Biography. Retrieved February 24, 2010 from

http://www.dnzb.govt.nz/dnzb/alt_essayBody.asp?essayID=4P20

Prakash, G. (1995). Orientalism now. History and Theory, 34 (3), 199212.

Priest, J. (1843). Slavery, as it relates to the negro, or African race, examined in the light of circumstances, history and the holy scriptures; with an account of the origin of the black man's color, causes of his state of servitude and traces of his character as well in ancient as in modern times: with strictures on abolitionism. Albany: C. Van Benthuysen \& Co.

Rangihau, J. (1992). Being Maori. In M. King (Ed.). Te ao hurihuri: Aspects of Maoritanga. Auckland: Reed.

Ranui, A. M. (2004). Brief of evidence of Alec Mahanga Ranui dated the $14^{\text {th }}$ day of March 2004. Wai 894/ Wai 726. Submission to the Waitangi Tribunal, Wellington, New Zealand.

Rata, E. (2004). Ethnic ideologies in New Zealand education: what's wrong with Kaupapa Maori? Teacher Education Forum for Aotearoa New Zealand Conference, Auckland College of Education, July 2004.

Rata, E. (2005). The rise and rise of the neotribal elite. Address to the Summer Sounds Symposium, Malborough Sounds, 11-13 February 2005.

Rata, E. (2006). The political strategies of ethnic and Indigenous elites. In E. Rata \& R. Openshaw (Eds.). Public policy and ethnicity: The politics of ethnic boundary marking (pp. 40-55). New York: Palgrave Macmillan.

Reed, A.W. (2002). Taonga Tuku Iho: Ilustrated encyclopaedia of traditional Māori life. Auckland: New Holland Publishers Limited.

Rees, R. A. (2004). Black African Jews, the modern denial of priesthood to blacks, and truth and reconciliation. Sunstone, 134, 62-67. Retrieved September 3, 2009 from https://www.sunstonemagazine.com/pdf/134-62-67.pdf.

Roberts, R. M. \& Wills, P. R. (1998). Understanding Maori epistemology: A scientific perspective. In H. Wautischer (Ed.). Tribal epistemologies: Essays in the philosophy of anthropology (pp. 43-77). England: Ashgate Publishing.

Romano, R. C. (2003). Race mixing: Black-white marriage in postwar America. London: Harvard University Press.

Root, M. (Ed.). (1992). Racially mixed people in America. Newbury Park, California: Sage Publications.

Rose, K. (2003). A people dispossessed: Ngati Haka Te Patuheuheu and the Crown, 1864-1960. Crown Forest Rental Trust.

Ross, W. Hugh. (1966). Te Kooti Rikirangi: General and prophet. Auckland: Collins.

Rusden, G. W. (2000 [1888]). Aureretanga: Groans of the Maoris. Christchurch: Kiwi Publishers. 
Rushton, J. P. (2000). Race, evolution, and behaviour: A life history perspective ( $2^{\text {nd }}$ edition, abridged). Port Huron, MI: Charles Darwin Research Institute. Retrieved September 3, 2009 from http://www.europeanamericansunited.org/school1/Eugenics/Ru shton/Race_Evolution_Behavior.pdf.

Said, E. (1978). Orientalism. London: Penguin.

Said, E. (1985). Orientalism reconsidered. Cultural Critique, 1, 89-107.

Saldanha, A. (2006). Reontologising race: The machinic geography of phenotype. Environment and Planning D: Society and Space, 24, 924. Retrieved September 4, 2009 available from http://scholar.google.co.nz/scholar?start=120\&q=race+and+repre sentation+colonial\&hl=en.

Salmond, A. (1978). Te ao tawhito: A semantic approach to the traditional Maori cosmos. Journal of the Polynesian Society, 87(1), 5-28.

Salmond, A. (1985). Maori epistemologies. In J. Overing (Ed.), Reason and morality (pp. 240-64). London: Routledge.

Salmond, A. (1991). Two worlds: First meetings between Maori and Europeans 1642-1772. Auckland: Viking.

Salmond, A. (1997). Between worlds: Early exchanges between Maori and Europeans 1773-1815. Auckland: Penguin.

Schmitt, R. (1996). Racism and objectification: Reflections on themes from Fanon. In L. R. Gordon., T. D. Sharpley-Whiting, \& R. T. White, Fanon: A critical reader. Oxford: Blackwell Publishers.

Schwimmer, E. (1966). The world of the Maori. Auckland: Reed.

Schwimmer, E. (1974). The world of the Maori. Wellington: Reed Education.

Scott, M. (2008). Edward Said's Orientalism. Essays in Criticism, 58 (1), 64-81.

Shavit, Y. (2001). History in black: African-Americans in search of an ancient past. London: Frank Cass Publishers.

Simon, J. (1990). The place of schooling in Maori Pakeha relations. Unpublished doctoral thesis, University of Auckland, Auckland, New Zealand.

Simon, J. \& Smith, L. T. (2001). A civilising mission: Perceptions and representations of the New Zealand native school system. Auckland: Auckland University Press.

Sinclair, K. (2002). Prophetic histories: The people of the Māramatanga. Wellington: Bridget Williams Books Limited.

Sissons, J. (1991). Te Waimana the spring of mana: Tuhoe history and the colonial encounter. Dunedin: University of Otago Press.

Smedley, A. (1997). Origin of the idea of race. Anthropology Newsletter. Retrieved August 31, 2009 available from http://scholar.google.co.nz/scholar?start=110\&q=great+chain + of +being+and+race\&hl=en.

Smith, D. (2003). The persistence of racialized discourse in Mormonism. Sunstone, 126, 31-33. Retrieved September 3, 2009 from http://sunstoneonline.com/magazine/issues/126/126-3133.pdf. 
Smith, D. (2009). Key concepts and theories about 'race'. In H. S. Bhui (Ed.), Race and criminal justice (pp. 9-29). London: Sage.

Smith, L. T. (1997). Maori women: Discourses, projects and mana wahine. In S. Middleton \& A. Jones (Eds.), Maori women and education 2 (pp. 33-51). Auckland: Auckland University Press \& Bridget Williams Books.

Smith, L. T. (1999). Decolonizing methodologies. Dunedin: Otago University Press.

Smith, P. (2001[1899]). On the Tohunga Maori. Christchurch: Kiwi Publishers. Transactions and proceedings of the Royal Society of New Zealand 1868-1961 (vol. 32, pp. 253-70). Retrieved September 29, 2009 from http://rsnz.natlib.govt.nz/volume/rsnz_32/rsnz_32_00_003720.h tml.

Smylie, J., Martin, C. M., Kaplan-Myrth, N., Steele, L., Tait, C. \& Hogg, W. (2004). Knowledge translation and Indigenous knowledge. International Journal of Circumpolar Health, 63(supp 2), 139-143. Proceedings of the 12th International Congress on Circumpolar Health, September 10-14, 2003, Nuuk, Greenland. Retrieved $16 \quad$ September, 2009 from http://ijch.fi/issues/63supp12/ICCH12_Smylie.pdf.

Snowden, F. M. (1983). Before colour prejudice: The ancient view of blacks. Harvard: Harvard University Press.

Spoonley, P., Macpherson, C., Pearson, D. \& Sedgwick, C. (1984). Tauiwi: Racism and ethnicity in New Zealand. Palmerston North: Dunmore Press.

Spoonley, P., Pearson, D. \& Macpherson, C. (1991). Nga take: Ethnics relations and racism in Aotearoa/New Zealand. Palmerston North: Dunmore Press.

Spoonley, P. (1995). Racism and ethnicity: Critical issues in New Zealand society. Auckland: Oxford University Press.

Spoonley, P., Pearson, D. \& Macpherson, C. (1996). Nga patai: Racism and ethnic relations in Aotearoa/New Zealand. Palmerston North: Dunmore Press.

Spoonley, P. (1996). Mahi awatea? The racialisation of work in Aotearoa/New Zealand. In P. Spoonley, D. Pearson, \& C. Macpherson (Eds.). Nga patai: Racism and ethnic relations in Aotearoa/New Zealand. Palmerston North: Dunmore Press.

Spoonley, P., Macpherson, C. \& Pearson, D. (2004). Tangata tangata: The changing ethnic contours of New Zealand. Southbank Victoria: Dunmore Press.

Stewart-Harawira, M. (2005). The new imperial order: Indigenous responses to colonisation. Wellington: Huia Publishers.

Stocking, G. W. (1968). Race, culture, and evolution: Essays in the history of anthropology. New York: The Free Press.

Stocking, G. W. (1987). Victorian anthropology. New York: The Free Press. 
Stokes, E., Milroy, W. J., \& Melbourne, H. (1986). People, land and forests of Te Urewera. Hamilton, New Zealand: University of Waikato.

Stoler, A. L. (1995). Race and the education of desire: Foucault's history of sexuality and the colonial order of things. Durham \& London: Duke University Press.

Sykes, A. (2006). The consequences of departing from Kaupapa Māori baselines. In A. Mikaere (Ed.), Mā te rongo te waka ka rere: Exploring a Kaupapa Māori organisational framework (pp. 90-104). Ōtaki: Te Wānanga-o-Raukawa.

Taipari, G. Maori protest sparks standoff. The Daily Post, 11 August 2009.

Taipari, G. Maori protesters threaten more road blocks. The Daily Post, 12 August 2009.

Tait, S. (1999). Advertising, cultural criticism and mythologies of the male body. In R. Law, H. Campbell, \& J. Dolan (Eds.). Masculinities in Aotearoa/New Zealand (pp. 189-214). Palmerston North: Dunmore Press.

Tamplin, R. (1992). Noble men and noble savages. In M. Gidley (Ed.). Representing others: White views of Indigenous peoples (pp. 6083). Exeter: University of Exeter Press.

Tauroa, H. (1989). Healing the breach: One Maori's perspective on the Treaty of Waitangi. Auckland: William Collins Publishers.

Te Awekotuku, N. (1991). He tikanga whakaaro: Research ethics in the Maori community. Wellington: Manatu Maori.

Thomas, D. H. (2000). Skull wars: Kinnewick man, archaeology and the battle for Native American identity. New York: Basic Books.

Thomas, D. \& Veno, A (Eds.). (1996). Community psychology and social change: Australian and New Zealand perspectives. Palmerston North: Dunmore Press.

Thomas, D. R. \& Nikora, L. W. (1996). From assimilation to biculturalism: changing patterns in Maori-Pakeha relationships. In D. Thomas \& A. Veno (Eds.), Community psychology and social change: Australian and New Zealand perspectives (pp. 231-56). Palmerston North: Dunmore Press.

Thompson, E. P. (1967). Time, work-discipline, and industrial capitalism. Past and Present, 38, 56-97.

Thompson, F. M. L. (1963). English landed society in the nineteenth century. London: Nicholson.

Thompson, E. P. (1978). The poverty of theory and other essays. London: Merlin Press.

Thomson, A. S. (1859). The story of New Zealand: Past and presentsavage and civilized. Vol. 1. London: John Murray.

Walker, R. (1990). Ka whawhai tonu matou: Struggle without end. Auckland: Penguin Books.

Walker, R. (1996). Nga pepa a Ranginui. The Walker papers. Auckland: Penguin Books.

Walker, S. (1996). Kia tau te rangimarie: Kaupapa Maori theory as resistance against the construction of Maori as the other. 
Unpublished master's thesis. University of Auckland, Auckland, New Zealand.

Wall, M. (1995). "Being a Maori is..." media constructions of the Maori 'race' as the black other. Unpublished master's thesis, University of Auckland, Auckland, New Zealand.

Wall, M. (1997). Stereotypical constructions of the Maori 'race' in the media. New Zealand Geographer, 53(2), 40-45.

Ward, A. (1995). A show of justice: Racial 'amalgamation' in nineteenth century New Zealand. Auckland: Auckland University Press.

Ward, A. (2009). A 'savage war of peace'? Motives for government policies towards the kingitanga, 1857-1863. In R. Boast \& R. S. Hill (Eds.). Raupatu: The confiscation of Maori land (pp. 67-108). Wellington: Victoria University Press.

Wautischer, H. (Ed.). (1998). Tribal epistemologies: Essays in the philosophy of anthropology. England: Ashgate Publishing.

Weaver, J. C. (2009). Land seizures and aftershocks: 'A true history lesson' on anglo-colonialism. In R. Boast \& R. S. Hill (Eds.). Raupatu: The confiscation of Maori land (pp. 48-59). Wellington: Victoria University Press.

Whitford, D. M. (2009). The curse of Ham in the early modern era: The bible and the

justifications of slavery. United Theological Seminary, USA: Ashgate.

Whitt, L. (2009). Science, colonialism, and Indigenous peoples: The cultural politics of law and knowledge. Cambridge: Cambridge University Press.

Williams, D. V. (1999). 'Te kooti tango whenua': The native land court 1864-1909. Wellington: Huia Publishers.

Williams, J. A. (1969). Politics of the New Zealand Maori: Protest and cooperation 1891-1909. Auckland: Auckland University Press \& Oxford University Press.

Wilson, B. (1975). The noble savage: The primitive origins of charisma and its contemporary survival. Los Angeles: University of California Press.

Wiri, R. (1994). Te wai-kaukau o nga matua tipuna: Myths, realities, and the determination of mana whenua in the Waikaremoana district. Unpublished masters thesis, Auckland University, Auckland, New Zealand.

Wiri, R. K. J. (2001). The prophecies of the great canyon of Toi: A history of Te Whäiti-nui-a-Toi in the Western Urewera mountains of New Zealand. Unpublished doctoral thesis, Auckland University, Auckland, New Zealand.

Wouden, A. (1980). Te Houhi, the land, the people and the school. Historical review, Journal of the Whakatane and District Historical Society, 28(1), 2-16.

Wright, M. (2004). Reed illustrated history of New Zealand: Illustrations form the Alexander Turnbull Library. Auckland: Reed Publishing.

Yamauchi, E. M. (2004). Africa and the bible. Michigan: Baker Academic. 
Yates-Smith, G. R. A. (1998). Hine! Hine! Rediscovering the feminine in Maori spirituality. Unpublished doctoral thesis, University of Waikato, Hamilton, New Zealand.

Yoon, H. (1986). Maori mind, Maori land. Berne: Peter Lang.

Young, R. J. C. (1992). Colonialism and humanism. In J. Donald \& A. Rattansi

(Eds.).'Race', culture and difference (pp. 243-251). London: Sage Publications.

Young, R. J. C. (1994). Egypt in America: black Athena, racism and colonial discourse. In A. Rattansi \& $\mathrm{S}$. Westwood (Eds.). On the Western front: Studies in racism, modernity and identity (pp. 15069). Cambridge: Polity Press.

Young, R. J. C. (1995). Foucault on race and colonialism, New Formations, 25, 57-65. Retrieved September 3, 2009 from http://www.robertjcyoung.com/Foucault.pdf. 